INTERNATIONAL MONETARY FUND

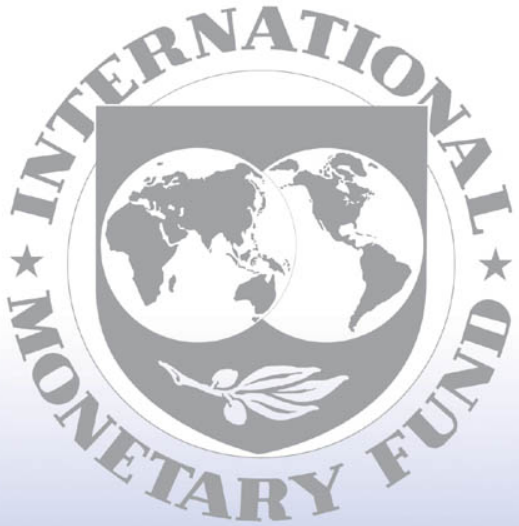

Staff

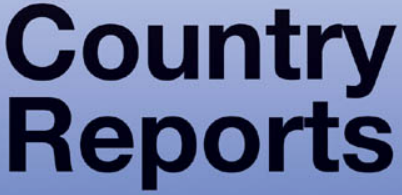




\title{
People's Republic of China-Hong Kong Special Administrative Region: 2004 Article IV Consultation--Staff Report; Staff Statement; and Public Information Notice on the Executive Board Discussion
}

Under Article IV of the IMF's Articles of Agreement, the IMF holds bilateral discussions with members, usually every year. In the context of the 2004 Article IV consultation with the People's Republic of China-Hong Kong Special Administrative Region, the following documents have been released and are included in this package:

- $\quad$ the staff report for the 2004 Article IV consultation, prepared by a staff team of the IMF, following discussions that ended on November 2, 2004, with the officials of People's Republic of China-Hong Kong Special Administrative Region on economic developments and policies. Based on information available at the time of these discussions, the staff report was completed on January 3, 2005. The views expressed in the staff report are those of the staff team and do not necessarily reflect the views of the Executive Board of the IMF.

- $\quad$ a staff statement of February 2, 2005 updating information on recent developments.

- a Public Information Notice (PIN) summarizing the views of the Executive Board as expressed during its February 2, 2005 discussion of the staff report that concluded the Article IV consultation.

The document listed below have been or will be separately released.

\section{Selected Issues Paper}

The policy of publication of staff reports and other documents allows for the deletion of market-sensitive information.

To assist the IMF in evaluating the publication policy, reader comments are invited and may be sent by e-mail to publicationpolicy@imf.org.

Copies of this report are available to the public from

$$
\begin{gathered}
\text { International Monetary Fund } \bullet \text { Publication Services } \\
70019^{\text {th }} \text { Street, N.W. • Washington, D.C. } 20431
\end{gathered}
$$

Telephone: (202) 623-7430 • Telefax: (202) 623-7201

E-mail: publications@imf.org • Internet: http://www.imf.org

Price: $\$ 15.00$ a copy

\author{
International Monetary Fund \\ Washington, D.C.
}




\section{INTERNATIONAL MONETARY FUND}

\section{PEOPLE'S REPUBLIC OF CHINA-HONG KONG SPECIAL ADMINISTRATIVE REGION}

\section{Staff Report for the 2004 Article IV Consultation Discussions}

Prepared by the Staff Representatives for the Consultation Discussions Held in 2004

In Respect of the Hong Kong Special Administrative Region

Approved by Wanda Tseng and Juha Kähkönen

January 3, 2005

- The consultation discussions were held in the Hong Kong Special Administrative Region of the People's Republic of China during October 26-November 2, 2004. The staff team comprised Mr. Prasad (Head), Messrs. Chamon and Leigh (all APD) and Mr. Craig (MFD). Mr. Gruenwald (Resident Representative) and Ms. Liu (Resident Representative's office) also participated in the mission. Messrs. Wang, Sun and Chen (OED) attended key meetings.

- The mission met with Financial Secretary Henry Tang, Chief Executive of the Hong Kong Monetary Authority Joseph Yam, Secretary for Financial Services and Treasury Frederick Ma, Chairman of the Securities and Futures Commission Andrew Sheng, and a wide range of other senior government officials, labor unions, academics and private sector representatives.

- In concluding the last Article IV consultation on May 16, 2003, Directors noted that the authorities faced significant policy challenges in the period ahead, against the background of a series of adverse shocks to the economy (including the outbreak of Severe Acute Respiratory Syndrome) and persistent deflation. They agreed that the appropriate policy response would be to intensify structural reforms to bolster Hong Kong SAR's competitiveness and long-term growth prospects. Directors endorsed the government's medium-term fiscal consolidation plan — noting that it would foster stability of the linked exchange rate system (LERS) - and expressed their support for the authorities' commitment to the LERS.

- The authorities have indicated their intention, as in the past, to publish the staff report.

- The principal author of this report is Lamin Leigh. 


\section{Contents}

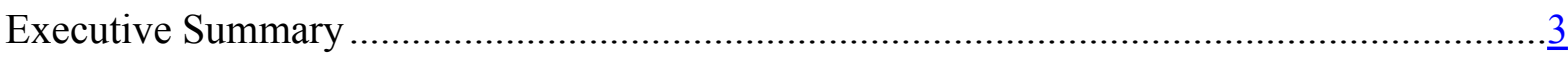

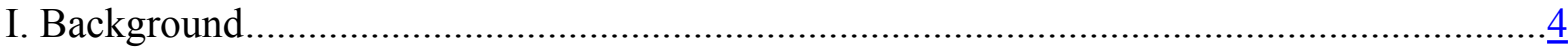

A. Recent Developments ......................................................................................

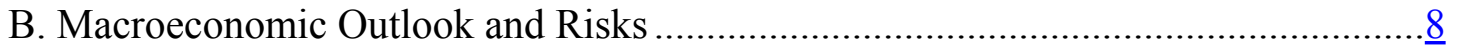

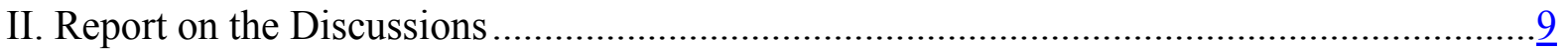

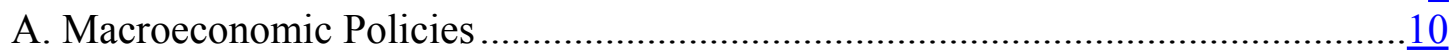

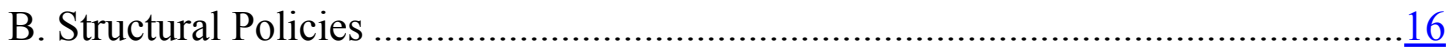

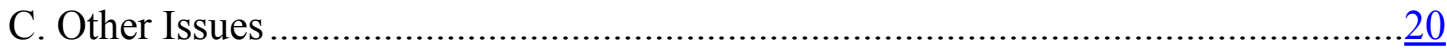

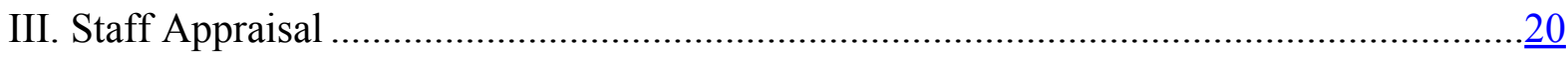

Boxes

1. Recent Appreciation Pressures on the Hong Kong Dollar...............................................

2. The Impact of Developments in Mainland China on Hong Kong SAR …….....................11

3. A Goods and Services Tax (GST) for Hong Kong SAR ................................................

4. Response of the Hong Kong SAR Government to Recommendations of the Financial Sector Assessment Program (FSAP)

Figures

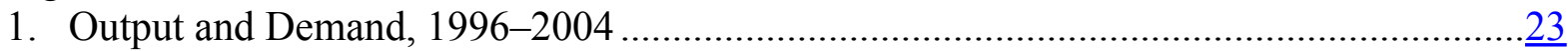

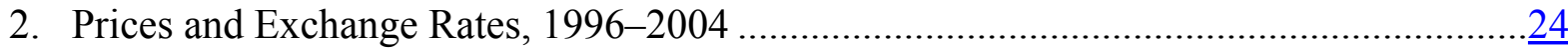

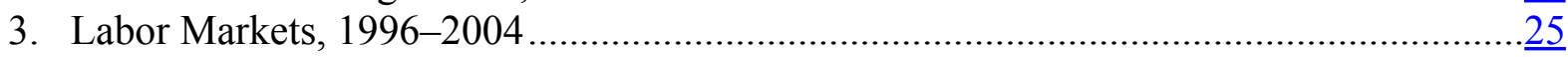

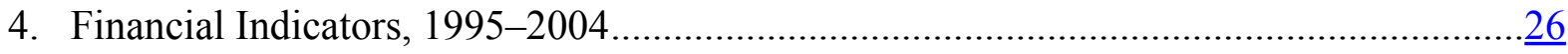

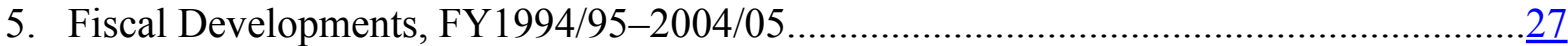

Tables

1. Selected Economic and Financial Indicators, 2002-2005 ……....................................28

2. Consolidated Government Accounts, FY2000-FY2008 …….....................................

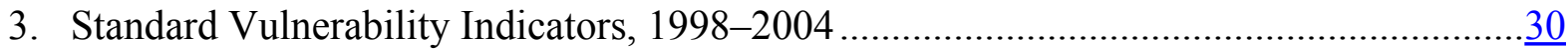

4. Medium-Term Macroeconomic Framework, 1999-2009...............................................

5. Medium-Term Balance of Payments, 1999-2009 ……………….................................

\section{Annexes}

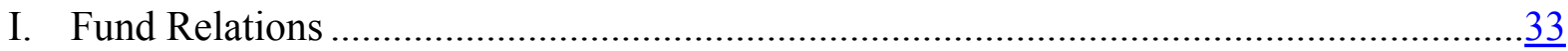

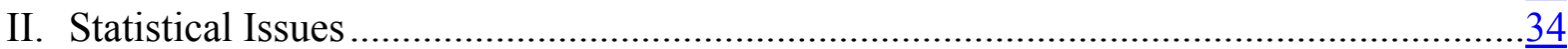




\section{EXECUTIVE SUMMARY}

\section{Economic Background}

- Hong Kong SAR's economic performance, which underwent a remarkable turnaround in the second half of 2003 , has strengthened and become more broadbased in 2004.

Real GDP grew by $83 / 4$ percent (year-on-year) in the first three quarters of 2004 (compared to $4 \frac{1}{2}$ percent in the second half of 2003), reflecting strong domestic demand and exports. The recovery was spurred by a surge in Mainland tourism to Hong Kong SAR, strong growth in the Mainland and a pick-up in global growth. CPI deflation appears to have ended, mainly reflecting strengthened demand conditions. The unemployment rate has fallen by almost 2 percentage points from its peak last year, but remained relatively high at 6.7 percent at end-November 2004.

The fiscal position has improved significantly - the consolidated fiscal deficit (before bond issuance) for FY2004/05 is projected at 13/4 percent of GDP (31/4 percentage points lower than budget) on account of buoyant revenues and continued expenditure restraint. However, the structural deficit is likely to be higher at about $3 \frac{1}{4}$ percent of GDP.

- $\quad$ Real GDP growth is expected to moderate to 4 percent in 2005 from $81 / 4$ percent in 2004, reflecting a slowing in global growth and some easing of activity on the Mainland. The risks to this central scenario are broadly balanced.

\section{Key Issues and Policy Discussions}

While the near-term outlook is positive, important policy challenges remain, including those stemming from the ongoing integration with the Mainland. Thus, the main focus of the mission's discussions was on the measures needed to foster robust and sustainable growth over the medium term.

On fiscal policy, the staff urged the authorities to take advantage of the current favorable macroeconomic environment and maintain continued expenditure restraint to forcefully address the long-standing structural deficit problem. The staff also encouraged the authorities to broaden and stabilize the revenue base through the introduction of a goods and services tax (GST), and adopt a longer-term focus for fiscal policy in light of Hong Kong SAR's demographic trends.

With regards to the exchange rate regime, the staff continues to support the authorities' commitment to the linked exchange rate system (LERS). The Hong Kong Monetary Authority's (HKMA) response to appreciation pressures on the Hong Kong dollar over the past year has enhanced the resilience of the LERS.

On structural policies, the staff noted that it is essential that Hong Kong SAR continue to strengthen its financial infrastructure as well as its supervisory and regulatory systems in order to maintain its position as a leading international financial center. Coordination of supervisory activities between Hong Kong SAR and the Mainland will become increasingly important as integration between the two economies intensifies. Tackling the problem of high unemployment and the structural weaknesses in the labor market remains a key policy priority. 


\section{BACKGROUND}

\section{A. Recent Developments}

1. After a period of prolonged weakness in economic activity, persistent deflation and rising fiscal deficits, the macroeconomic outlook has improved significantly since mid-2003. Following a sharp output decline and large capital outflows during the Asian crisis, the economy went through intermittent waves of recovery followed by recession. The recovery in late 2002 proved short-lived due to the outbreak of Severe Acute Respiratory Syndrome (SARS) in the second quarter of 2003. Domestic demand plunged, consumer price deflation intensified, the fiscal deficit increased and the Hong Kong dollar came under renewed depreciation pressures. The overall impact of SARS was short-lived, however, and the economy rebounded sharply in the third quarter. Since then, deflationary pressures have eased, the fiscal deficit has declined significantly and the Hong Kong dollar has been under appreciation pressures.

\section{2. $\quad$ Real GDP grew by}

3.2 percent in 2003 (up from

1.9 percent in 2002), led mainly by strong exports. The turnaround in the second half of the year was initially driven by net exports, with domestic demand picking up only in the fourth quarter. The recovery was spurred by a combination of continued strong growth in the Mainland, the package of policy measures approved by the Mainland authorities for Hong Kong SAR and the global recovery.

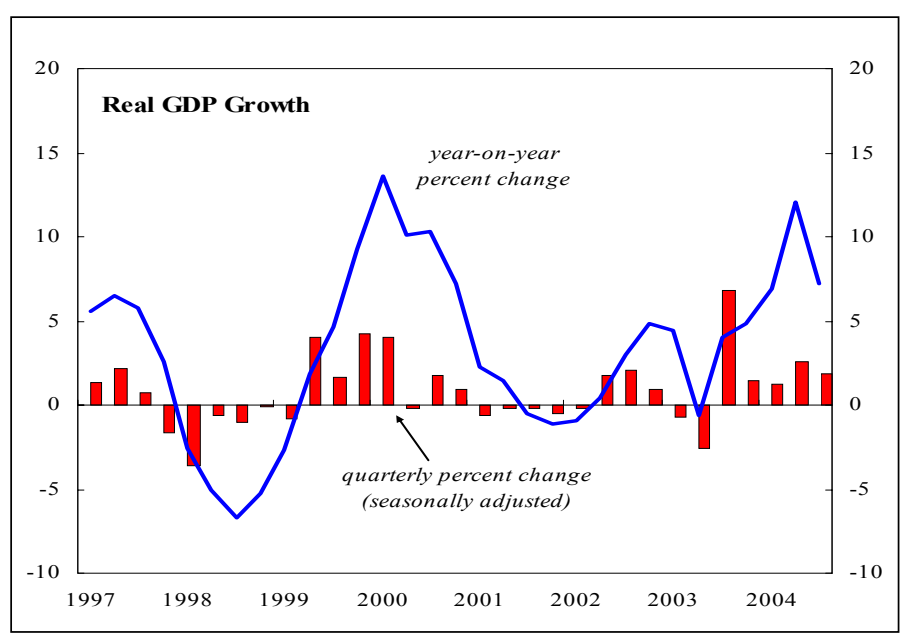

${ }^{1}$ The Closer Economic Partnership Arrangement (CEPA) was signed in mid-2003 and includes the easing of restrictions on individual travel from some areas of the Mainland to Hong Kong SAR. On January 1, 2004, about 90 percent of Hong Kong SAR's direct exports of goods to the Mainland became eligible for a zero-tariff treatment and Hong Kong SAR obtained wider market access for services through the lowering of entry barriers in the Mainland. The second phase of CEPA was signed on August 27, 2004, expanding the market access under the first phase of CEPA. 
3. The growth momentum strengthened in 2004, underpinned by robust domestic demand as well as continued strong export growth. Real GDP grew by an average of $83 / 4$ percent (year-on-year) in the first three quarters of 2004 (compared to $4 \frac{1}{2}$ percent in the second half of 2003). In particular, investment spending rose significantly, reflecting improved business sentiment in part due to the CEPA free trade agreement with China. Export growth strengthened in the first three quarters of 2004, driven largely by strong growth in the Mainland and the associated improvement in intra-regional trade. Import growth was also robust during the first three quarters of 2004 reflecting the pick-up in economic activity. However, the pace of job creation remains modest-although the employment rate has increased in 2004, with increased labor market participation the unemployment rate has declined only marginally from its level in December 2003 (Figure 3). Overall credit growth also remains sluggish despite the recovery.

\section{Consumer price deflation appears to have ended, reflecting strengthened} demand conditions, the stabilization of the overall property market and higher import prices. After persistent price declines for over 5 years, deflationary pressures eased rapidly from mid2003. The CPI index rose slightly during July-November 2004, in line with strengthened demand conditions. Prices of retained imports increased due to higher world commodity prices and, to a lesser extent, a weaker U.S. dollar. ${ }^{2}$ The decline in the GDP deflator, which has lagged behind the recovery in the CPI index due to terms of trade changes, has also moderated

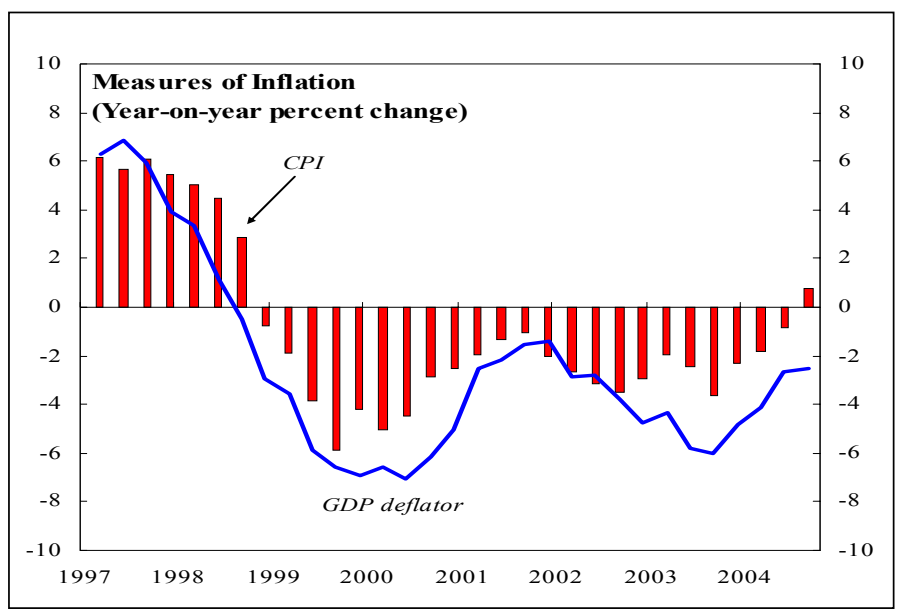
significantly in 2004.

5. Asset prices have recovered sharply but remain well below their peak. The property market (especially the luxury end of the market) has picked up after mid-2003. Residential property prices bottomed out in July 2003 and have soared by 40 percent since then, but remain well below their peak in October 1997 (Figure 2). Commercial property prices have also rebounded. After a protracted decline since 2000, the stock market has done

\footnotetext{
${ }^{2}$ Staff estimates indicate that the exchange rate pass-through to consumer prices is low, reflecting pricing-to-market adjustments in response to exchange rate changes.
} 
better over the past year (Figure 4). The Hang Seng index has increased by about 70 percent since its trough in April 2003. With the recovery of asset prices, both the banking and household sectors' balance sheets have improved. ${ }^{3}$

\section{The Hong Kong dollar has come under appreciation pressures since late}

September 2003. Following the issuance of the G-7 Communiqué calling for greater exchange rate flexibility in Asia on September 22, 2003, the Hong Kong dollar faced significant appreciation pressures, resulting in its trading at a discount in the forward market. ${ }^{4}$ On that day, the Hong Kong dollar spot rate also experienced a small (11/4 percent) but virtually unprecedented appreciation relative to the linked rate (Box 1). Appreciation pressures dampened during April to September 2004, but reemerged in late October 2004 on account of renewed speculation about a revaluation of the

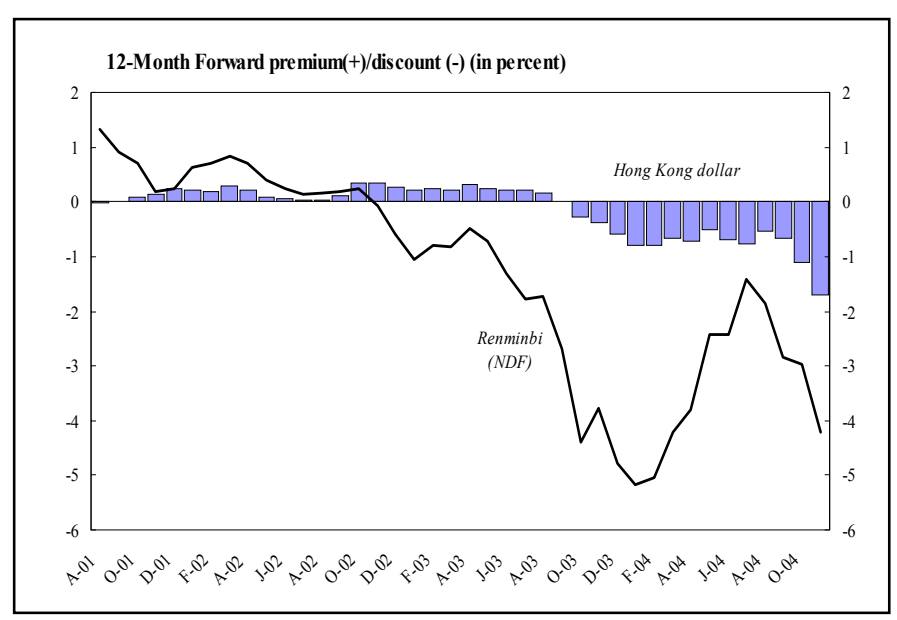
renminbi.

7. Hong Kong SAR's overall external position remains strong. The current account surplus rose to $103 / 4$ percent of GDP in 2003, reflecting increases in the invisible trade surplus and net external factor income. It narrowed to 4 percent of GDP in the first half of 2004 as imports recovered. Official reserves increased by US $\$ 6 \frac{1}{2} 2$ billion in 2003 and rose further in 2004 to about \$125 billion at the end of November 2004.

\section{The FY2003/04 deficit outturn was significantly better than targeted in the}

budget. The overall fiscal deficit was HK $\$ 40$ billion (3.2 percent of GDP) for the fiscal year ending March 31, 2004, compared to the budget target of about HK $\$ 68$ billion (5.3 percent of GDP). This improvement is significant, especially in view of the additional temporary fiscal measures that were taken during the year to mitigate the impact of SARS,

3 The average consolidated capital adequacy ratio stood at 15.9 percent at endSeptember 2004 and nonperforming loans fell to 2.7 percent of total loans. The number of homeowners with negative equity fell to about 25,400 (which accounts for 5 percent of all mortgage borrowers) at end-September 2004.

${ }^{4}$ Between 2002 and August 2003, a rapidly growing Mainland and a deflationary environment in Hong Kong SAR led some investors to take short positions on the Hong Kong dollar and long on the renminbi, contributing to the negative correlation between the 12-month forward rates. The release of the G-7 Communiqué resulted in appreciation pressures on both currencies and a positive correlation between their 12-month forward rates. 


\section{Box 1. Recent Appreciation Pressures on the Hong Kong Dollar}

Following a prolonged period of weak-side pressures on the Hong Kong dollar, significant strong-side pressures emerged in the second half of 2003. Slow growth, rising budget deficits, high unemployment and persistent deflation had resulted in downward pressures on the local currency during most of the post-Asian crisis period. These factors were compounded by the impact of the SARS outbreak in early 2003 . Weak-side pressures began to ease with the announcement of growth-enhancing measures from the Mainland in mid-2003 and the broadening of the global recovery. The reversal of sentiment was complete following market reaction to the G-7 Communiqué of September 2003, which called for upward flexibility in Asian currencies.

The HKMA responded to the burst of strong-side pressures by letting the spot rate appreciate below the linked rate. Since the adoption of "technical" measures in September 1998 designed to strengthen the currency board, the spot rate for the Hong Kong dollar had never been allowed to stray more than one basis point below the linked rate. While the measures included a commitment by the HKMA to buy Hong Kong dollars at the linked rate, there was no such commitment on the strong side - the currency board has the possibility of being "asymmetric." In the event, on September 22, 2003 the spot rate appreciated by $1 \frac{1 / 4}{4}$ percent.

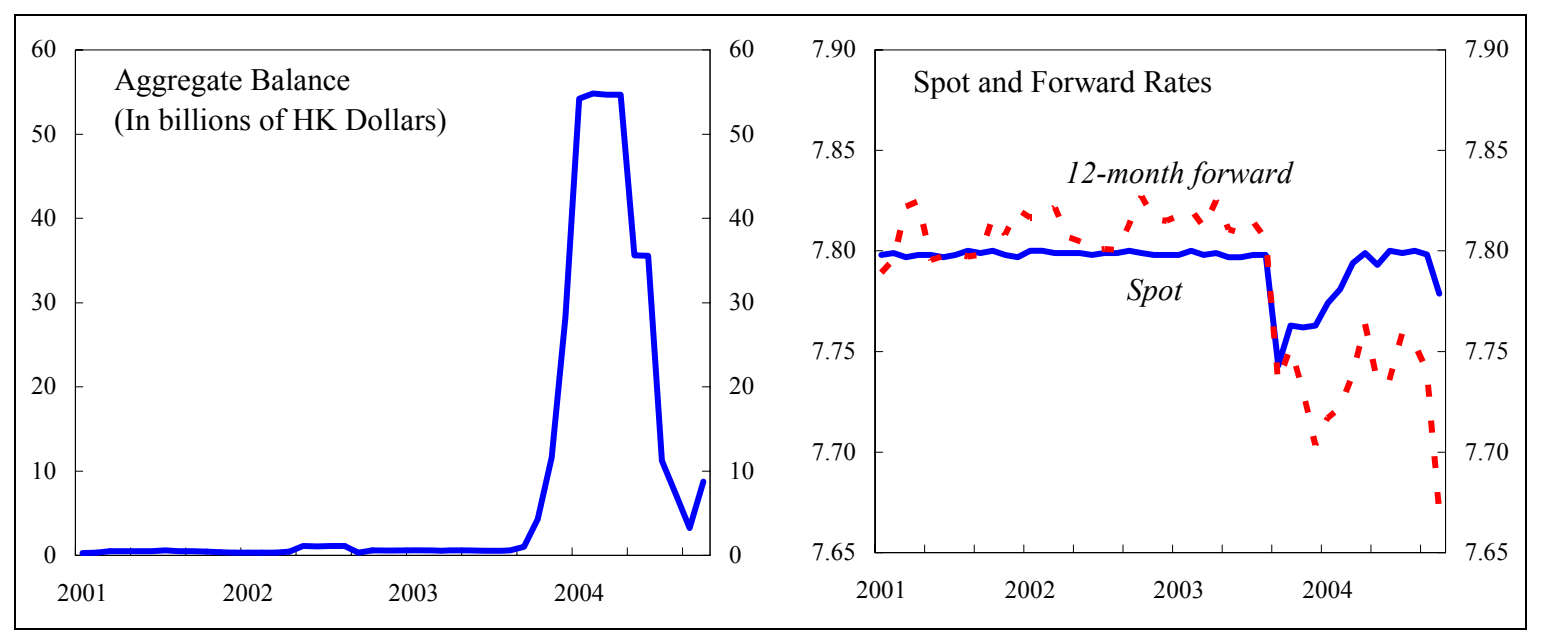

There was some uncertainty in the market in the ensuing period, but the HKMA was successful in gradually bringing the spot rate back to the linked rate. The market eventually came to a fuller understanding of the potential asymmetry of the exchange rate regime, and the volatility in the local foreign exchange market soon abated. The HKMA employed a strategy of "randomized" sales of Hong Kong dollars while nursing the spot rate back to the link in order to inject a degree of constructive ambiguity into the process. As a result of the sale of Hong Kong dollars, the aggregate balance (the Hong Kong dollar counterpart of the U.S. dollars purchased by the currency board) shot up to an unprecedented HK\$55 billion. By April 2004, the spot rate had returned to the linked rate, and the aggregate balance began to return to normal levels.

Significant strong-side pressures on the Hong Kong dollar re-emerged in late 2004, largely as a spillover from heightened expectations of a revaluation of the Chinese renminbi. The HKMA again allowed the spot rate to appreciate below the linked rate (albeit this time by less than $1 / 2$ percent) and, as a result, the aggregate balance once again began to climb. The 12-month forward contract surged to an unprecedented discount of 15 basis points by end-November 2004, implying expectations of about 2 percent appreciation of the currency. 
and reflects broader expenditure restraint (including civil service wage cuts) and higher-thanexpected investment income from the fiscal reserves.

\section{The consolidated fiscal deficit for FY2004/05 is now projected at about}

$13 / 4$ percent of GDP, compared with the budget target of about 5 percent of GDP. Data for the first half of FY2004/05 show an overall budget deficit (before bond issuance) of about $\mathrm{HK} \$ 50$ billion (which is about 30 percent lower than the deficit figure for the corresponding period for last year). ${ }^{5}$ The improvement relative to the budget is on account of buoyant revenue performance (reflecting stronger growth and large proceeds from land sales) and continued expenditure restraint. Fiscal reserves are projected at about 13 months of expenditures at the end of this fiscal year, well

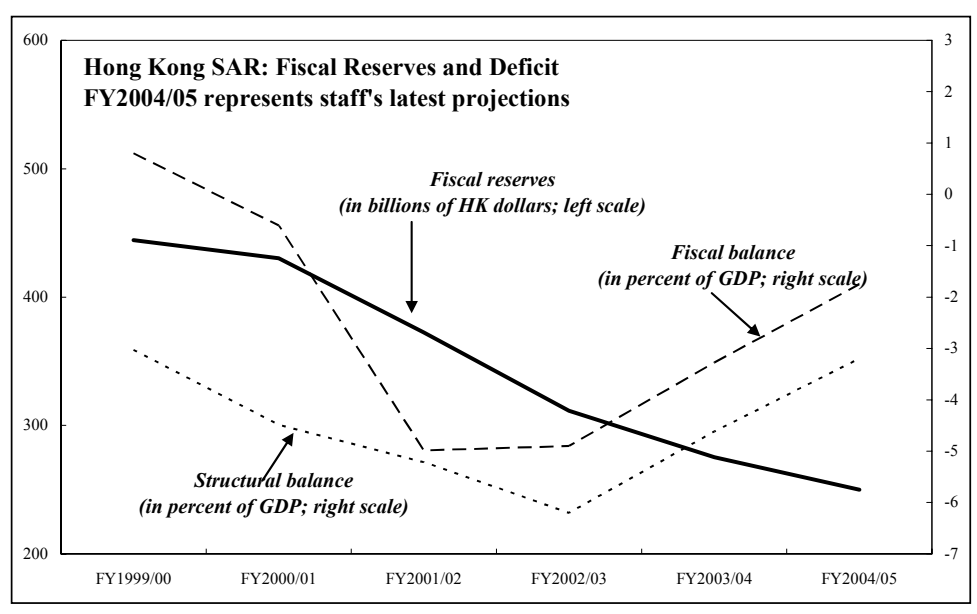
above the budget target of 10 months.

\section{The Fund's policy advice to the Hong Kong SAR authorities has contributed to} the process of policy formulation. Since the 2003 Article IV consultation, Hong Kong SAR has made significant progress on fiscal consolidation in line with the Executive Board's recommendations. The authorities' concerted efforts at expenditure restraint have been in line with staff advice, notwithstanding the low level of public support for these measures against the backdrop of the prolonged weakness in economic activity and a deflationary environment. The recent rapid growth that has been fueled by policy measures taken by the Mainland seems to have allayed these public concerns. The authorities have also implemented most of the recommendations of the 2003 FSAP report.

\section{B. Macroeconomic Outlook and Risks}

\section{Real GDP growth is expected to moderate to potential in 2005, with the risks}

broadly balanced. The staff projects that real GDP growth will decline to 4 percent in 2005 , reflecting a slowing in global growth and some easing of activity on the Mainland. CPI

\footnotetext{
${ }^{5}$ In interpreting this half-year outcome, it should be noted that tax revenues in Hong Kong SAR are lumpy as a large share of revenues from profits and salaries tax comes in the latter part of the fiscal year. It should also be noted that the government issued bonds amounting to about HK $\$ 26$ billion (2 percent of GDP) in April and July of 2004 to finance capital spending. Bond sales are counted by the government as revenues rather than as financing items. The government does not have any immediate plans for another bond placement.
} 
inflation is expected to remain subdued in 2005 . With employment growth in the range of $2-2 \frac{1}{2}$ percent in 2005 , the unemployment rate should fall below 6 percent. The risks to the outlook are mostly external. The downside risks are related to the durability of the global expansion, including the possible effects of persistently high oil prices. ${ }^{6}$ On the upside, there is some potential for stronger inbound tourism and more robust intra-regional trade.

\section{Sustained robust growth over the medium term will depend largely on the extent to which Hong Kong SAR meets the challenges of integration with the Mainland.}

- $\quad$ CEPA is expected to foster deeper trade and investment linkages between the two economies. ${ }^{7}$ In addition, the ongoing integration of the Mainland into the global economy is likely to benefit Hong Kong SAR, given its position as a gateway for foreign investors into the Mainland as well as for Mainland corporates venturing abroad.

- $\quad$ Competition from regions within the Mainland as well as from other financial centers in Asia implies that Hong Kong SAR will need to continue to bolster its competitiveness by complementing its traditional strengths-flexible product and factor markets, and strong institutions - with sound macroeconomic policies and productivity-enhancing reforms.

- $\quad$ Assuming that these efforts are successful, the staff projects that medium-term GDP growth in Hong Kong SAR will average about 4 percent. Inflation should remain low and stable over the medium term, in part reflecting ongoing, modest deflationary pressures stemming from continued integration with the Mainland.

\section{REPORT ON THE DISCUSSIONS}

13. Against the background of good near-term prospects, the main focus of this year's consultation discussions was on the measures needed to foster robust and sustainable growth over the medium term. The authorities and the staff concurred that, while the near-term outlook is positive, important policy challenges remain. These include

\footnotetext{
${ }^{6}$ Higher oil prices are unlikely to directly derail the economic recovery given Hong Kong SAR's predominantly service-based economy and small manufacturing sector. However, a persistent increase in oil prices could have a significant effect through its impact on Hong Kong SAR's major trading partners. The impact on consumer prices is likely to be small as the weight of oil-related components in the CPI basket is only about 1 percent.

${ }^{7}$ While the impact of the zero-tariff aspect of the CEPA agreement on merchandise trade by itself is likely to be small given the size of Hong Kong SAR's manufacturing sector (4 percent of GDP), the direct and indirect impact of the service sector liberalization component of CEPA (including tourism) is expected to become increasingly significant over time.
} 
the necessary strengthening of the public finances and managing the ongoing integration with the Mainland. ${ }^{8}$ Deeper integration with the Mainland has already resulted in significant changes in the structure of Hong Kong SAR's re-export trade and its labor market (Box 2). Adapting to these dynamic changes in its trade patterns and forcefully tackling the structural weaknesses in the labor market will be critical to enhancing Hong Kong SAR's external competitiveness and ensuring continued strong growth over the medium term. The staff also noted that it will be essential for Hong Kong SAR to continue strengthening its financial infrastructure as well as its supervisory and regulatory systems in order to maintain its position as a leading international financial center.

\section{A. Macroeconomic Policies}

\section{Fiscal Policy}

14. The staff encouraged the authorities to take advantage of the current favorable macroeconomic environment to forcefully address the long-standing structural deficit problem. It now appears likely that, on a consolidated basis, budget balance can be achieved well before the target date of FY2008/09. ${ }^{9}$ The staff projects that, if the expected overperformance in fiscal adjustment (on the consolidated balance) is realized in FY2004/05 and "locked in," the consolidated budget could be brought almost into balance in FY2005/06 (Table 2). ${ }^{10}$ However, the underlying structural fiscal deficit is projected to be about $1 \frac{1}{2}$ percent of GDP in FY2005/06. ${ }^{11}$ The staff stressed that eliminating the structural deficit is essential as this would:

- $\quad$ Facilitate Hong Kong SAR's adjustment to cyclical shocks as well as structural shifts related to the Mainland's integration with the global economy;

- $\quad$ Mitigate any future downward pressures on the linked exchange rate system; and

- Help to accommodate future fiscal pressures that are related to demographic changes.

\footnotetext{
${ }^{8}$ Chapter I of the Selected Issues Paper characterizes the rapid expansion of Hong Kong SAR's economic ties with the Mainland and analyzes the implications of the growing linkages.
}

${ }^{9}$ In the FY2004/05 budget, the authorities announced a two-year postponement of the target date for balancing the budget in response to the uncertain macroeconomic environment in early 2004 (the target date announced in the FY2003/04 budget was FY2006/07).

10 "Locking in" the gains made in FY2004/05 assumes that the total expenditures are kept unchanged in nominal terms in FY2005/06.

${ }^{11}$ The structural budget balance excludes investment income, land premium, asset-related receipts, equity injections and cyclical effects. 


\section{Box 2. The Impact of Developments in Mainland China on Hong Kong SAR}

\section{The Hong Kong SAR and Mainland economies have become increasingly linked, resulting in significant changes in the structure of Hong Kong SAR's economy.}

- As manufacturing has moved to the Mainland over the last two decades, the share of the manufacturing sector in Hong Kong SAR's GDP has declined from about 24 percent in 1980 to about 4 percent now. Most of the manufacturing that has migrated to the Mainland is largely labor intensive. This structural transformation of Hong Kong SAR's economy towards knowledge-based and high-value-added activities has led to the erosion of the demand for low-skilled workers. As a consequence, the unemployment rate has risen faster among low-skilled workers.

- $\quad$ The structure of trade between Hong Kong SAR and the Mainland is changing rapidly, reflecting China's increased access to world markets. Thus, the share of Hong Kong SAR's entrepôt trade (as a ratio to China's trade) has declined significantly, and it is increasingly getting a share of "offshore" or "transshipment" trade that takes advantage of its superior logistical services. However, the valueadded of this type of trade is significantly lower than that of traditional re-export trade.

- As China's capital account is highly regulated and its capital markets are still underdeveloped, fund raising by Mainland companies in Hong Kong SAR continues to be significant. Hong Kong SAR's cumulative investment in the Mainland amounted to nearly 76 percent of Hong Kong SAR's GDP in 2003. This data includes FDI in China by foreign-owned firms incorporated in Hong Kong SAR. However, it probably also includes FDI that is "round tripped" via Hong Kong SAR and back to China to take advantage of the favorable tax treatment for foreign firms.

The growing integration of Hong Kong SAR and the Mainland has been reflected in increasing correlation between their economic cycles. The correlation between the two economies' output as well as the components of output have increased since the mid-1990s, which suggests that integration has advanced in many sectors of the two economies. Forward exchange rates have become highly correlated and equity market developments in the two economies have generally followed each other.

\section{The increasingly close links between the Mainland and Hong Kong SAR imply that} macroeconomic fluctuations in China could have large spillover effects on

Hong Kong SAR. A sharp slowdown in growth on the Mainland could affect Hong Kong SAR's economy through a variety of channels including trade links, Mainland tourism and investment earnings. The impact on Hong Kong SAR banks' profitability and asset quality is likely to be negligible as domestic banks' direct exposure to Mainland entities is relatively small. Staff analysis shows that a one-time 10 percentage point decline in China's import growth for domestic consumption due to a slowdown in domestic investment growth would lower Hong Kong SAR's growth in 2004 by about $1 / 2$ percentage point after multiplier effects are incorporated. The current account surplus would be reduced only marginally since both imports and exports would be affected almost proportionally. 
15. The authorities concurred with the staff that eliminating the structural deficit as soon as possible is a key policy priority. The FY2004/05 budget targets a deficit of $23 / 4$ percent of GDP in FY2005/06. However, this is based on a conservative growth projection compared to the current staff forecast, which suggests that revenue overperformance is likely. The staff recommended that, consistent with the existing policy rules, all overperformance on revenues (relative to the revenue targets in the FY2004/05 budget) be used to replenish fiscal reserves. ${ }^{12}$ The Financial Secretary (FS) signaled his resolve to bolster the fiscal consolidation effort, including by further tightening expenditure control in the context of the forthcoming FY2005/06 budget. ${ }^{13}$

\section{Expenditures will bear the brunt of the authorities' medium-term fiscal} consolidation efforts. The staff commended the authorities for the expenditure restraint shown last year and so far this year. The expenditure to GDP ratio in FY2003/04 (191/2 percent excluding the temporary spending to mitigate the impact of SARS) was nearly 1 percentage point lower than budget and indications are that a similar performance is likely in FY2004/05 (Table 2). Over the medium term, total expenditure is slated to decline to about 16 percent of GDP, mainly through downsizing of the civil service. Rationalizing and reforming social programs and holding the line on social spending will also be key to achieving the medium-term objective. Expenditures on education, health, and welfare now account for nearly 50 percent of total expenditures (Figure 5) ${ }^{14}$ In particular, welfare spending has doubled over the last decade, in part due to a generous social transfer system. ${ }^{15}$ The authorities broadly concurred with the staff on the need to rationalize social spending. In this respect, they considered that the recent welfare reforms instituted in the CSSA and reforms to the education and health care systems would help to contain the rise in social spending over the medium term. The government has recently revamped the fee structure of its public health care services to contain rising health care costs, including the introduction of a new charge for accident and emergency services. The authorities also plan to encourage the provision of health care by the private sector.

\footnotetext{
${ }^{12}$ The staff noted that alternative options to increase the level of fiscal reserves such as the use of bond issuance, would implicity mean that the proceeds from bond sales would finance current expenditures. This could reduce fiscal discipline and may not be viewed favorably by the markets.
${ }^{13}$ The FY2005/06 budget will be presented to the Legislative Council on March 16, 2005.
${ }^{14}$ Staff analysis presented in IMF Occasional Paper No. 226 discusses various measures to curb rising education and health spending.

15 The government has so far resisted recent calls to reverse the welfare reform measures that were approved in 2003. These included adjustments in the standard payment rates for the Comprehensive Social Security Assistance (CSSA) program to account for past deflation, as well as a tightening of the eligibility requirements for the CSSA. 


\section{The staff reiterated its recommendation to broaden the tax base and stabilize} revenues through the adoption of a goods and services tax (GST). Hong Kong SAR's tax base remains narrow by international standards. In addition, some important sources of revenue, including asset sales and investment income, tend to be quite volatile. The staff argued, on grounds of economic efficiency, that a GST remains the best option to reform the tax regime and reduce over-reliance on volatile revenue sources. A GST would also lessen the need to raise rates on salaries and profits taxes. As the government has relied on these taxes for increasing revenues in the past few years, further increases in their rates could hurt Hong Kong SAR's competitiveness. The staff emphasized that preparations for the introduction of a GST should start soon, given the long lead time required for its implementation. In line with the recommendations of the IMF's Technical Assistance report that was prepared in May 2004, the staff underscored that the GST should be set up with minimal exemptions (Box 3). In particular, the staff argued that the GST is an instrument for revenue generation in the most neutral manner possible and is ill-suited to achieve other economic and social objectives, for which superior instruments could be found. ${ }^{16}$

\section{The authorities agreed with the staff on the need to introduce a GST. The}

Financial Secretary (FS) concurred that broadening the revenue base and shifting it towards more stable sources was a high priority, and indicated his intention to introduce a GST over the medium term. The FS indicated that the first step would be to engage in extensive public consultations in order to build social consensus, but noted that planning for a GST could start even before a formal decision was taken on its introduction. The FS expressed his appreciation for the technical assistance provided by the IMF on the design of a GST that would be best suited to Hong Kong SAR's needs and economic structure.

\section{The staff noted that demographic trends are likely to impose a burden on the} public finances over the long term. While Hong Kong SAR's dependency ratio of about 35 percent is low compared to those of its neighbors, it is projected to double by 2030 . Hence, spending on health, longer-term care and welfare-which already account for a substantial portion of government spending (about 25 percent of total expenditures) - are likely to increase over time. The associated rise in pension liabilities is, however, not expected to be a major source of fiscal pressures. ${ }^{17}$ Civil servants have a defined-benefit

\footnotetext{
${ }^{16}$ A GST rate of 5 percent (the current rate in Japan and Singapore) would probably increase the cost of the consumption basket of the poor by about 3.3 percent. A commensurate upward adjustment in the benefits available under Hong Kong SAR's CSSA could be an effective means to protect the economically vulnerable segments of the population.

${ }^{17}$ Staff analysis suggests that demographic changes would generate significant fiscal stress over the longer run, with age-related spending peaking around 2050 at about 8 percentage points of GDP higher than the level today. Of this increase, only about $1 \frac{1}{2}$ percentage points would be due to higher pension expenditures. However, given the very low level of public debt (2 percent of GDP), this does not raise any long-term fiscal sustainability issues.
} 


\section{Box 3. A Goods and Services Tax for Hong Kong SAR}

In response to a request from the Hong Kong SAR authorities for further advice on policy and administrative issues in introducing a goods and services tax (GST), staff from the IMF's Fiscal Affairs Department visited Hong Kong SAR in April 2004 and held extensive discussions with the authorities.

\section{The main findings of this technical assistance (TA) mission's report are as follows:}

It would be desirable to broaden Hong Kong SAR's tax base. Hong Kong SAR has one of the lowest tax revenue/GDP ratios in the world (about 10.5 percent in FY2003/04), stemming largely from its extraordinarily narrow tax base. About 60 percent of the tax revenue is usually derived from taxes on salaries and profits. While low taxes bring obvious economic benefits, they also pose inevitable difficulties for the public finances: the narrow tax base has proved problematic for addressing Hong Kong SAR's long-standing structural budget deficit problem.

The base of a GST would come conceptually very close to the combined base of Hong Kong SAR's existing salaries and profits tax. The estimated revenue yield of a broad-based GST (with minimal exemptions and zero-ratings) in Hong Kong SAR would be about 0.37 percent of GDP for every percentage point of the GST rate - a figure that is comparable to the observed performance of the GST in other countries of the region. Thus, the report concludes that the argument for introducing a GST in Hong Kong SAR could be based on the fact that having a GST would lessen the need to raise salaries and profits taxes for mobilizing needed budgetary resources.

A GST is first and foremost an instrument of revenue generation in the most neutral manner possible; it is ill-suited to achieve other economic and social objectives for which superior instruments could be found. Hence, it would not be advisable to burden the GST with features largely designed to address equity concerns, such as food exemptions. A commensurate upward adjustment in the benefits available under Hong Kong SAR's comprehensive social security assistance scheme could be an effective means to protect the vulnerable segments of the population.

The treatment of financial services and immovable properties under a GST remain major issues under deliberations, due to the importance of these two sectors in Hong Kong SAR's economy. The TA report recommends that the financial sector should either be zero-rated, or exempted but with provision of partial input tax recovery. As regards immovable properties, the report reiterated the preferred GST treatment: the sale and rental of commercial properties, whether new or existing, should be fully taxable, while only the sale of new residential properties should be taxed. Residential rental payments should be exempt to preserve neutrality between rental and owner-occupied housing services.

Concerns about possible revenue leakage of introducing the GST on the destination basis are valid since Hong Kong SAR has no tariffs and its customs administration is not experienced in the collection of duties and taxes on imports on a broad scale. However, the report also notes that these concerns should not be exaggerated, as much of the value of imports destined for domestic consumption in Hong Kong SAR would be recaptured in the tax base even if it escapes taxation at the import stage.

On tax administration aspects of the GST, the report notes that the GST is traditionally administered by the same department that collects income taxes and that there is no reason why the Inland Revenue Department could not handle the GST; structurally, at least in the medium term, setting up a separate GST division within that department is a sensible approach. The liability of imports into Hong Kong SAR to pay the GST will require a major change in the operations of the Customs and Excise Department. The TA report outlined the type of new controls that will be needed to achieve a desirable balance between customs control and trade facilitation. 
pension system and pension outlays in the budget currently account for only 1 percent of GDP. Moreover, the Mandatory Provident Fund scheme, which came into operation in December 2000 and is privately managed, will also provide a growing source of retirement income by 2030. The staff recommended that the authorities develop an anchor to guide longerterm fiscal policy that takes into account potential fiscal pressures that are likely to arise from factors such as changing demographics. Such a fiscal anchor could focus on the government's overall balance sheet and could include targeting a

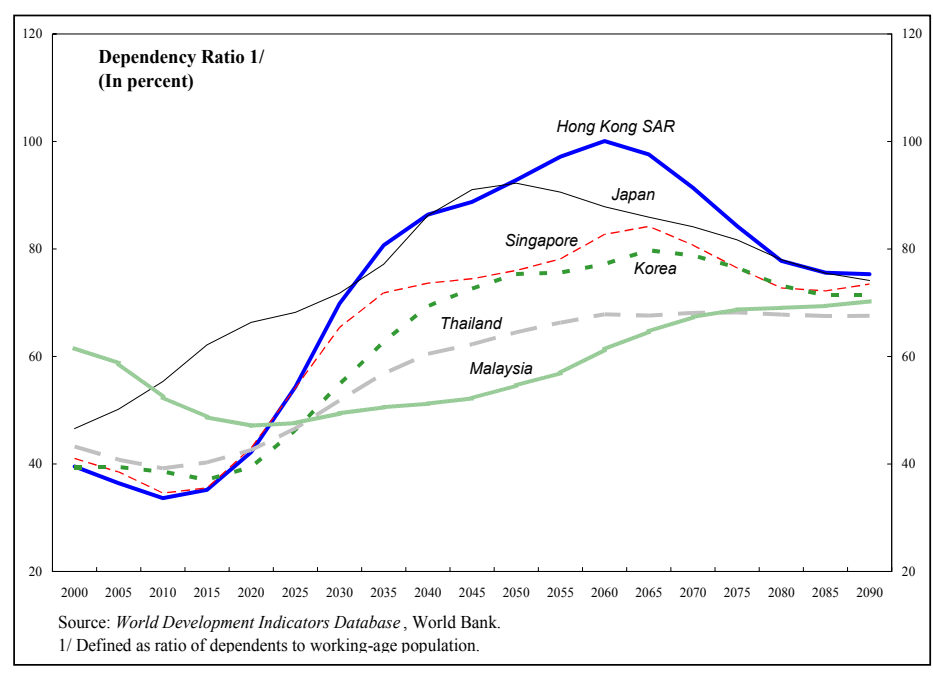
higher level of fiscal reserves or net government assets.

\section{The authorities concurred that the fiscal implications of demographic trends} warranted further attention. They are in the process of conducting a formal intergenerational analysis to identify the sources and potential magnitudes of these fiscal pressures. In addition, they are taking steps to alleviate the likely pressures on the budget, including through better control of health care costs and by facilitating the emigration of elderly CSSA recipients to Guangdong and Fujian provinces. ${ }^{18}$

\section{The Linked Exchange Rate System (LERS)}

\section{The LERS has responded well to strong-side pressures on the Hong Kong dollar} over the past year and remains robust. Under the LERS, there is no explicit commitment by the Hong Kong Monetary Authority (HKMA) to sell the Hong Kong dollar on the strong side of the linked exchange rate. In response to the significant appreciation pressures on the Hong Kong dollar that emerged in late September 2003, the HKMA used this asymmetry and allowed a modest temporary appreciation (Box 1 provides a more detailed description of this episode). The authorities argued that the potential risks associated with the use of this flexibility were limited so long as the HKMA used its discretionary powers sparingly and cautiously. The staff agreed that the HKMA's response to appreciation pressures had enhanced the resilience of the LERS. ${ }^{19}$

\footnotetext{
${ }^{18}$ Such schemes would encourage retirees to emigrate to the Mainland while allowing them to maintain some access to their retiree benefits in Hong Kong SAR.
}

${ }^{19}$ Chapter II of the Selected Issues Paper analyzes this episode of strong-side pressures on the Hong Kong dollar, including the efficacy of the HKMA's policy response. 
22. The staff reiterated its support for the authorities' commitment to the LERS. A move towards greater exchange rate flexibility in the rest of Asia (especially Mainland China) could induce some short-term speculative pressures on the Hong Kong dollar, but is unlikely to pose significant challenges for Hong Kong SAR, given its strong internal and external positions and the HKMA's track record. Internal and external balance considerations suggest that the real effective value of the Hong Kong dollar appears to be broadly consistent with fundamentals. ${ }^{20}$

\section{B. Structural Policies}

\section{The financial system remains resilient to a variety of macroeconomic shocks.}

Banks are well capitalized and their asset quality has improved as the share of non-performing loans in total loans has declined following the economic recovery. The profitability of retail banks improved in 2003 as the decline in net interest margins (due to intense competition and weak demand for credit) was more than offset by lower provisioning charges and the increase in non-interest income. A slowdown in the Mainland is not likely to have a major impact on Hong Kong banks' profitability and asset quality as domestic banks' direct exposure to Mainland entities is small. ${ }^{21}$ An increased holding of debt securities has made banks more susceptible to bond market volatility, although the impact should be limited given better tools to hedge interest rate risk.

\section{The staff noted that, while property loans have not proven riskier than other} loans, their share in total loans has increased and this concentration could represent a more significant source of risk in the future. ${ }^{22}$ The authorities argued that banks' increasing concentration in the property sector was mainly due to weak credit demand by the other sectors. They also noted that the loan-to-deposit ratio remains low by historical standards and that the HKMA maintains a conservative prudential limit of 70 percent on the loan to value ratio. The household sector's overall debt burden remains manageable and is not likely to be significantly affected by an increase in interest rates. The corporate sector's balance sheet is strong - most firms continue to register record profits and, at 40 percent, their leverage (measured by the debt to net worth ratio) remains low.

\footnotetext{
${ }^{20}$ The output gap is closed, the fiscal position has improved markedly, external competitiveness remains adequate, and pressures in the foreign exchange market have in general been quite mild.

${ }^{21}$ However, banks also have some indirect exposure arising from the Mainland activities of borrowers, although data to assess these activities are lacking.

${ }^{22}$ Chapter III of the Selected Issues Paper discusses this and other aspects of the financial system, including regulatory and supervisory structures, and how they may have an influence on financial sector procyclicality in Hong Kong SAR.
} 
25. The authorities have made considerable progress in the implementation of FSAP recommendations to strengthen financial sector regulation and supervision (Box 4). The staff also commended the authorities for the recent passage of legislation to introduce a deposit insurance scheme; its launch in 2006 will further strengthen the banking system. ${ }^{23}$ In addition, preparations for the adoption of Basel II requirements by banks are proceeding well. The staff noted that enhanced cross-industry supervisory coordination has become more important as banks and other financial institutions expand the scope of their businesses due to intensifying competitive pressures. Thus, banks are seeking to diversify into fee-based activities, including by offering more complex financial products. Adjusting to this new business environment represents a challenge for the banks.

\section{Progress has been made in improving cooperation with Mainland supervisory} counterparts in the banking, securities and insurance industries, but important challenges remain. Banks incorporated in Hong Kong SAR can now open branches on the Mainland under a lower asset requirement (US\$6 billion from a previous requirement of US\$20 billion) as part of the CEPA agreement. Moreover, large Mainland banks are increasingly using Hong Kong SAR as a financial center. The HKMA signed a memorandum of understanding with the China Banking Regulatory Commission in August 2003 to strengthen supervision of banks operating on both sides of the border (Box 4). A similar level of cooperation exists between the Securities and Futures Commission in Hong Kong SAR and the China Securities Regulatory Commission in the Mainland for supervision of the securities industry. On the insurance front, the Insurance Authority of Hong Kong SAR entered into a cooperative agreement with the China Insurance Regulatory Commission in November 2004. However, a great deal of work remains to be done to enhance broader coordination of financial sector regulation and supervision, especially given the substantial differences in legal frameworks between the two economies. The authorities agreed that this would become increasingly important as the integration of the two economies intensifies. Sustained efforts in these areas will be necessary to deal with rising competition from aspiring financial centers in the region.

\section{Tackling the problem of high unemployment, which partly reflects structural} factors, is a key policy challenge. The ongoing structural transformation of the Hong Kong SAR economy towards knowledge-based and high value added activities has led to the erosion of the demand for low-skilled workers. Thus, the unemployment rate has risen faster among low-skilled workers and the wage premium commanded by high-skilled labor has increased. ${ }^{24}$

${ }^{23}$ In May 2004, the Legislative Council passed a law to institute a deposit protection scheme in 2006. The scheme will be managed by an independent statutory body, the Hong Kong Deposit Protection Board, which was formed on July 1, 2004. The scheme is expected to be established over a period of 18-24 months. In order to prevent moral hazard and ensure the financial viability of the scheme, the amount of protection for each eligible claim is to be capped at HK $\$ 100,000$ and there will be a system of differential contributions by banks based on their regulatory ratings.

${ }^{24}$ At the same time, Mainland family-based immigration to Hong Kong SAR has contributed to an increased supply of low-skilled workers (about $1 / 2$ percent of the labor force per annum). 


\section{Box 4. Response of the Hong Kong SAR Government to Recommendations of the Financial Sector Assessment Program (FSAP)}

While the FSAP, which was concluded in 2003, found the financial system to be robust and fundamentally sound, some improvements in financial sector supervision and regulatory governance arrangements were recommended. This box outlines actions taken to date by the government in response to the main FSAP recommendations, which appear in bold; the authorities' actions appear in plain text.

Further strengthen regulatory governance arrangements and improve the transparency of institutional and policy frameworks. The terms of reference of the Council of Financial Regulators and the Financial Stability Committee were published in late June 2003. At the same time, the responsibilities delegated to top finance officials, including the Financial Secretary and Secretary for Financial Services and the Treasury were clarified, with policy formation and execution responsibilities clearly separated. A formal statement of monetary policy aims was also released, which made explicit that the operating mandate of the Hong Kong Monetary Authority (HKMA) is to maintain exchange rate stability.

Enhance cross-industry supervisory coordination. The HKMA and Insurance Authority (IA) signed a memorandum of understanding (MOU) in September 2003 outlining their respective responsibilities for regulating banks' insurance business. Under the MOU, the HKMA is responsible for the daily regulation of banks' insurance business. In cases of complaints of malpractice, the two regulators will share investigative work and take disciplinary action as needed. With regard to the distribution of listing functions among the statutory regulator - the Securities and Futures Commission (SFC) — and the market operator Hong Kong Exchanges and Clearing (HKEx), the government announced its decision in March 2004 to let the HKEx remain the frontline regulator to vet listing applications. It also announced its intention to give statutory backing to major listing requirements (including financial reporting and other periodic disclosure, disclosure of price-sensitive information and shareholders' approval for certain notifiable transactions) which would be enforced by the SFC. The relevant legislative amendments would be introduced to the Legislature in 2005.

Strengthen cross-border information sharing mechanisms and regulatory arrangements, in particular with the Mainland. The HKMA signed a MOU with the China Banking Regulatory Commission (CBRC) in late August 2003 to strengthen supervision of banks operating on both sides of the border. The MOU calls for the HKMA and the CBRC to share supervisory information on banks operating in the Mainland and Hong Kong SAR, and to ensure that a parent bank will exercise "adequate and effective" control over the operations of its cross-border branches and subsidiaries. The two regulators will also meet twice a year.

Improve corporate governance by fostering shareholder participation, ensuring equitable treatment of minority shareholders, improving the frequency and quality of reporting, and enhancing board oversight. The Standing Committee on Company Law Reform concluded its comprehensive corporate governance review in January 2004. The Companies Ordinance was amended in July 2004 to make it easier for investors to seek compensation for unfair connected transactions involving major shareholders. Other proposals of the consultation paper include adding statutory backing to listing rules, forcing companies to rotate their lead auditor partner every five years, and specifying the remuneration of individual directors.

Establish an independent legal basis for the IA in order to bring Hong Kong SAR into line with international practice and improve oversight of the insurance industry. The Hong Kong SAR government has finished its consultation on the proposal to turn the IA into a self-funded independent regulatory body. Opinions and views collected from the consultation are being examined by the Financial Services and Treasury Bureau in Hong Kong SAR. The government's aim is to develop a detailed proposal for the establishment of the independent authority in consultations with relevant stakeholders in the next 12 months.

Enhance data collection and monitoring to better assess potential vulnerabilities to the financial system. Policy notes have been issued on interest rate, liquidity and foreign currency risk assessment, and the HKMA is helping banks to develop and put in place stress testing techniques. 
Staff analysis shows that the overall degree of mismatch in the labor market has risen (Figure 3) and so has the average duration of unemployment, leading to an increase in longterm unemployment. The staff supported the government's proposed reforms to the education system and its ongoing retraining and skills-upgrading programs (including plans to consider support for private provision of education, which would help move toward a more efficient investment in education). The staff noted that the social safety net also has an important role to play in facilitating the movement of displaced workers to growing industries, although it should minimize disincentives to seek employment. The staff noted that the high degree of flexibility of Hong Kong SAR's labor market has traditionally delivered good outcomes. Therefore, maintaining this flexibility will be essential to facilitate adjustment to shifts in the structure of the economy.

\section{The property market has rebounded, reflecting the economic recovery; the government continues its efforts to reduce its direct involvement in this market. The} recovery in overall property prices appears to be broadly in line with improving economic fundamentals, including better prospects for income growth. The government's intervention in the land market has contributed to movements in property prices. Over the past year, the government has taken further steps to withdraw from active involvement in this market. Effective January 1, 2004, government land is being sold only through the Application List, which is a market-oriented system. ${ }^{25}$ Three land auctions were held between May-November of 2004 using the Application List system. In June 2004, the Housing Authority announced that it would release for sale up to 26,000 public rental flats by end-2004, while also eliminating its loan scheme for low income home buyers in the private market. The staff noted that continued provision of timely information about the government's plans concerning the supply of land would help reduce uncertainty and mitigate any associated instability in property prices.

\section{Hong Kong SAR continues to maintain one of the most liberal trade regimes in}

the world. The authorities noted that trade liberalization measures agreed under CEPA are likely to be expanded in the future. The authorities indicated that they were open to exploring free trade agreements with other trading partners, so long as these were consistent with WTO principles and provisions and contribute to multilateral trade liberalization. The government's approach towards competition continues to be based on a sector-specific approach rather than a comprehensive competition law. The government's approach aims to address high firm concentration in certain sectors, reduce barriers of entry, and encourage business investment by local and foreign firms.

${ }^{25}$ Under this system, the government announces in advance which lots will be available for sale (by auction or tender) in the coming year. An interested party can trigger the auction of a lot by submitting a price bid acceptable to the government. The land is then auctioned or tendered publicly to the highest bidder. 


\section{Other Issues}

30. The authorities produce and disseminate a comprehensive set of economic statistics. Hong Kong SAR provides data to the IMF on a timely basis for surveillance and publication, and is fully compliant with the IMF's Special Data Dissemination Standards (SDDS). Since June 2002, the authorities have published data on the international investment position and gross external debt. Hong Kong SAR has for the first time reported Government Finance Statistics (GFS) data for publication in the 2003 GFS Yearbook. The authorities also publish data on the direction of services trade, which is important given its growing importance for economic activity.

31. The staff noted that fiscal transparency could be enhanced as current practice is not fully consistent with international best practices in some respects. The staff commended the authorities for taking the initiative to move from a cash-based approach to an accrual-based presentation of the fiscal accounts starting with the FY2002/03 fiscal data. The staff encouraged the authorities to publish mid-year fiscal budget outturns with a comprehensive breakdown of revenues and expenditures and an analysis of how the mid-year estimates compare with the budget.

\section{The HKMA has put in place a good framework for Anti-Money Laundering.} The HKMA, SFC, and the Office of the Commissioner of Insurance have issued guidelines (that do not require changes in legislation) to their respective regulated entities in implementing international requirements for AML. The authorities plan to put the AML guidelines into effect in 2005. Additional measures to comply with the 40 recommendations of the Financial Action Task Force that do need changes to legislation were discussed in the Legislative Council in October 2004. A bill aimed at effecting related amendments is to be introduced into the Legislative Council in the last quarter of 2005.

\section{STAFF APPRAISAL}

33. The economic recovery, in tandem with supportive policy measures, has fostered good progress in strengthening Hong Kong SAR's macroeconomic outlook. The recovery became more broad-based in 2004, driven by the package of policy measures approved by the Mainland authorities for Hong Kong SAR and the global recovery. CPI deflation appears to have ended against the backdrop of robust domestic demand.

Expenditure restraint and revenue buoyancy have led to a significant decline in the fiscal deficit. This progress on the macroeconomic front bodes well for continued strong growth in the near term, although there remain risks to the outlook, stemming mainly from uncertainties in the external environment.

\section{Sustaining strong growth over the medium term will depend crucially on} effectively meeting the challenges of integration with the Mainland. Eliminating the long-standing structural deficit problem, tackling structural unemployment, and managing the ongoing integration with the Mainland are key challenges. The ongoing integration of the Mainland into the global economy is likely to benefit Hong Kong SAR, 
given its position as a gateway for foreign investors into the Mainland as well as for Mainland corporates venturing abroad. At the same time, competition from regions within the Mainland as well as from other financial centers in Asia implies that Hong Kong SAR will need to continue to bolster its competitiveness by complementing its traditional strengths - flexible product and factor markets, and strong institutions - with sound macroeconomic policies and productivity-enhancing reforms.

\section{The staff encourages the authorities to take advantage of the current favorable} macroeconomic environment to eliminate its long-standing structural deficit problem. Fiscal performance in Hong Kong SAR has improved markedly over the past two years and a relatively early attainment of budget balance on a consolidated basis seems likely. However, the structural balance is expected to remain in deficit for a longer period. The staff urges the authorities to take measures that would eliminate the structural deficit as soon as possible. This would help bolster fiscal reserves, facilitate adjustment to shocks that the economy might face and mitigate any future downward pressures on the LERS.

\section{Continued expenditure restraint is essential to ensure a credible and lasting}

fiscal consolidation. The staff commends the authorities for their expenditure restraint in the current upturn and advises locking in these gains in order to more rapidly reduce the expenditure-to-GDP ratio, which would be consistent with Hong Kong SAR's model of small government. In particular, this will require careful monitoring of the civil service wage bill and adequate control of social expenditures. The staff supports the maintenance of a strong and well-targeted social safety net, with rules-based adjustments to benefits.

\section{Broadening the tax base and stabilizing revenues through the adoption of a GST} remains a key policy priority. The staff considers a GST as the best option for improving the efficiency of the tax regime and reducing the reliance on volatile revenue sources. It could also enhance revenue buoyancy in a non-distortionary manner. The staff welcomes the authorities' plans to engage in extensive public consultations in order to build social consensus on the introduction of a GST. Given the long lead time required, however, technical preparations for the implementation of a GST will need to get underway soon.

\section{The staff encourages the authorities to develop an anchor to guide longer-term} fiscal policy that accounts for demographic trends. In view of Hong Kong SAR's rapidly aging population, the government will need significant fiscal resources in the long run. Such a fiscal anchor could consider targeting a higher level of fiscal reserves or net government assets, which would further enhance the credibility of the LERS. More generally, it would be useful if the authorities could emphasize this longer-term focus for fiscal policy in subsequent budgets as public awareness of the issue appears limited.

\section{The HKMA's response to appreciation pressures over the past year has}

enhanced the resilience of the LERS. The LERS remains robust and the staff continues to support the authorities' commitment to it. 
40. The staff welcomes recent measures taken by the authorities to further enhance the financial sector's resilience to macroeconomic shocks. The passage of legislation to introduce a deposit insurance scheme is a positive development; its launch in 2006 will further strengthen the banking system. In addition, the staff welcomes progress made in the preparations for the adoption of Basel II guidelines by banks. On the other hand, while property loans have not proven riskier than other loans, their share in banks' loan portfolios has increased markedly and could therefore represent a more significant source of risk in the future. The staff urges continued vigilance in monitoring bank lending to the property sector.

\section{It is important for Hong Kong SAR to continue strengthening its financial} infrastructure as well as its supervisory and regulatory systems in order to maintain its position as a leading international financial center. The staff commends the Hong Kong SAR authorities for implementing the recommendations of the 2003 FSAP report, including the enhancement of regulatory and supervisory arrangements. Enhanced cross-industry supervisory coordination has become more important as banks and other financial institutions expand the scope of their businesses in response to intensifying competitive pressures. The staff welcomes the progress that has been made in improving cooperation with Mainland supervisory counterparts in the banking and securities industries. Coordination of supervisory activities between the two economies will become increasingly important as their integration intensifies. Sustained efforts in all of these areas will be necessary to deal with rising competition from aspiring financial centers in the region.

42. The progress made by the government in reducing its direct involvement in the property market is welcome and these efforts need to continue. The introduction of the Application List for land sales has resulted in a more market-based system. The staff welcomes recent steps taken by the government to further limit its involvement in the property market. Continued provision of timely information about the government's plans concerning the supply of land would help reduce uncertainty and mitigate any associated instability in property prices.

43. Tackling the high level of structural unemployment is a key policy priority. The outsourcing of manufacturing and low-end service sector jobs to the Mainland has reduced the relative demand for low-skilled workers in Hong Kong SAR. The staff supports the government's proposed reforms to the education system and its ongoing retraining and skillsupgrading programs. The social safety net has an important role to play in facilitating the movement of displaced workers to growing industries, although it should also minimize disincentives to seek employment. The staff encourages the authorities to maintain Hong Kong SAR's labor market flexibility, which has traditionally delivered good outcomes and will help facilitate adjustment to further shifts in the structure of the economy.

44. It is recommended that the next Article IV consultation with the People's Republic of China in respect of Hong Kong SAR take place on a 12-month cycle. 
Figure 1. Hong Kong SAR: Output and Demand, 1996-2004

After contracting significantly in 2003Q2 due to the impact of SARS, real GDP growth rebounded in $2003 \mathrm{H} 2$ and strengthened in the first three quarters of $2004 . .$.

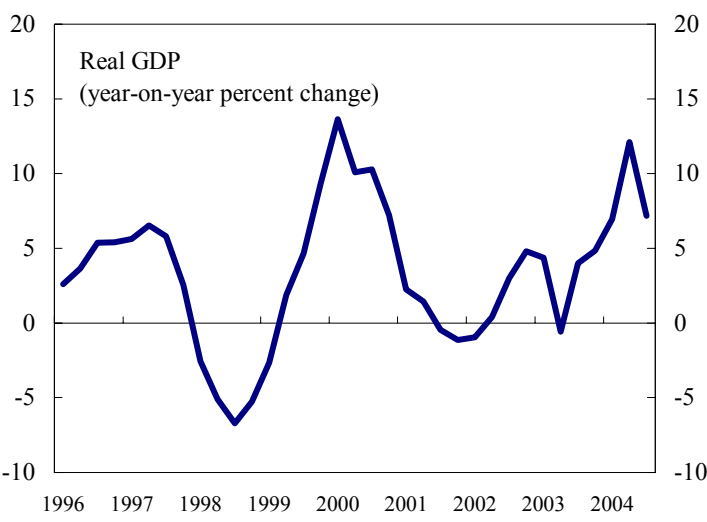

Net exports were the key driver of growth in 2003, but domestic demand has led growth in 2004...
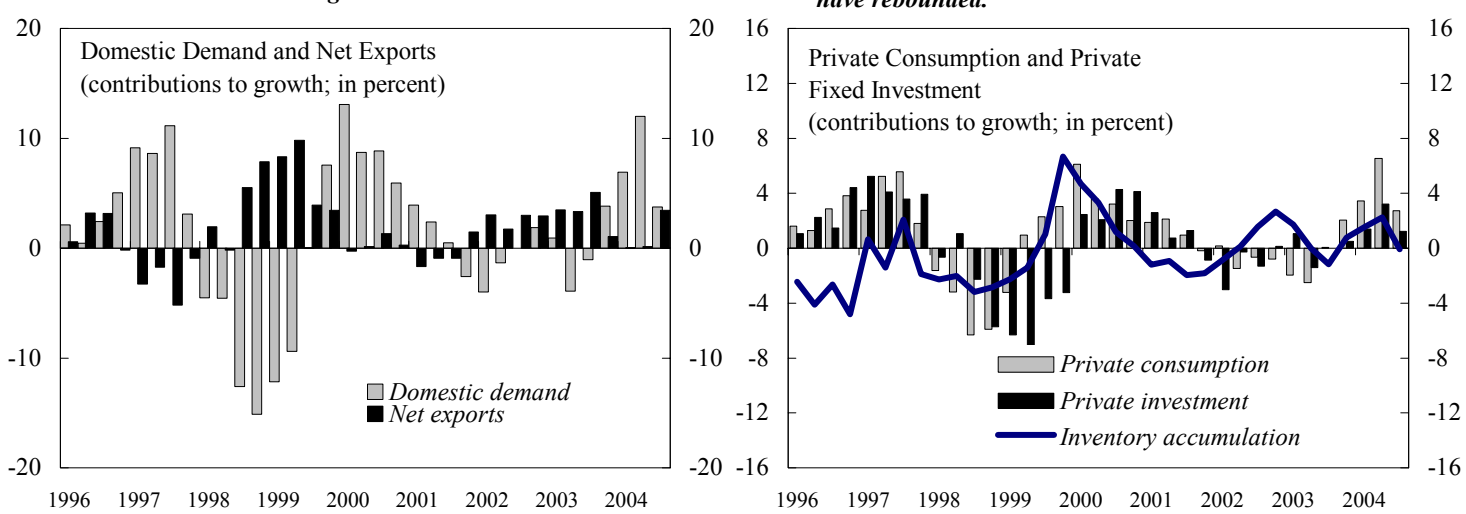

....and the output gap is projected to close by end-2004.

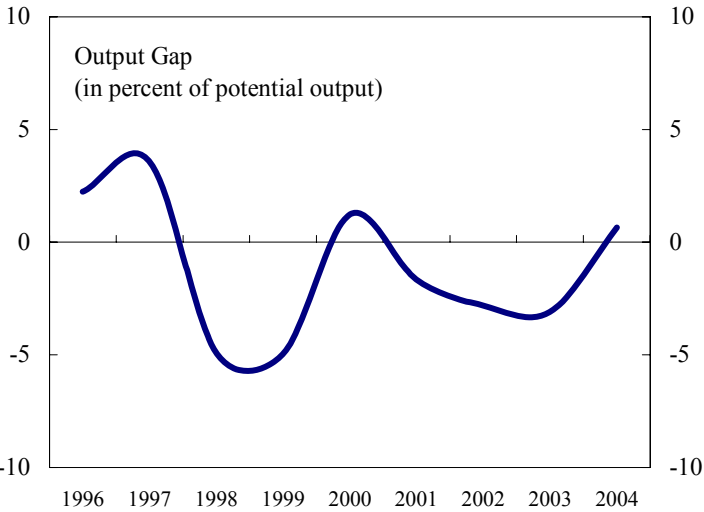

... as both consumption and investment spending have rebounded.

Export and import growth continue to be strong...
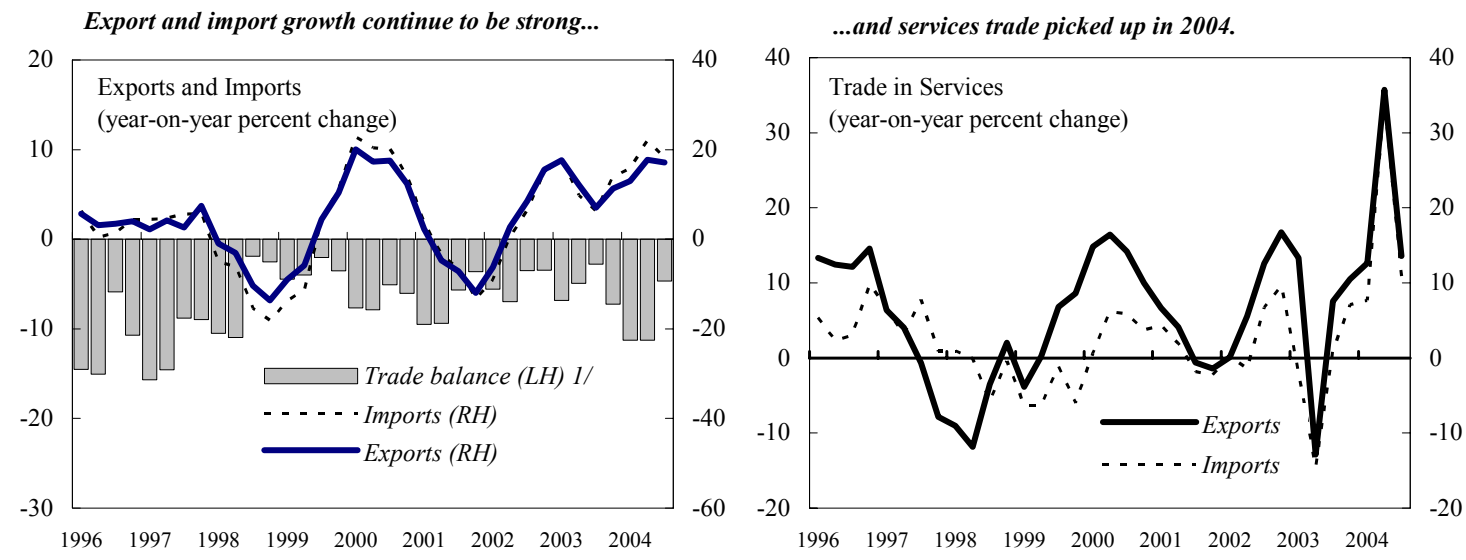

Sources: Data provided by the Hong Kong SAR authorities; and staff estimates.

1/ Trade balance in percent of GDP. 
Figure 2. Hong Kong SAR: Prices and Exchange Rates, 1996-2004

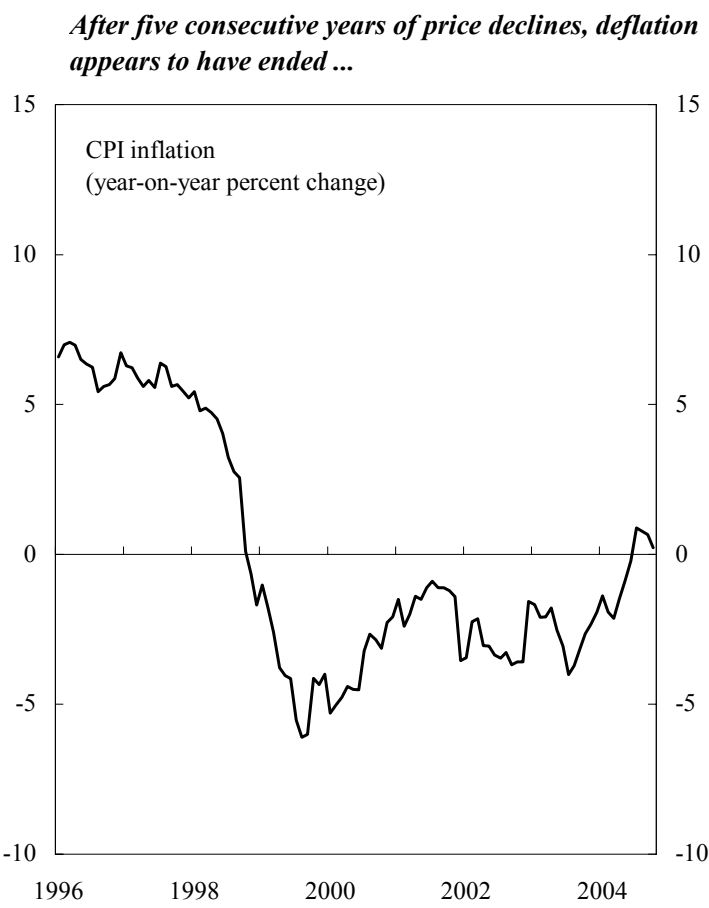

...driven by the recovery of non-housing prices, and to some extent, housing prices.

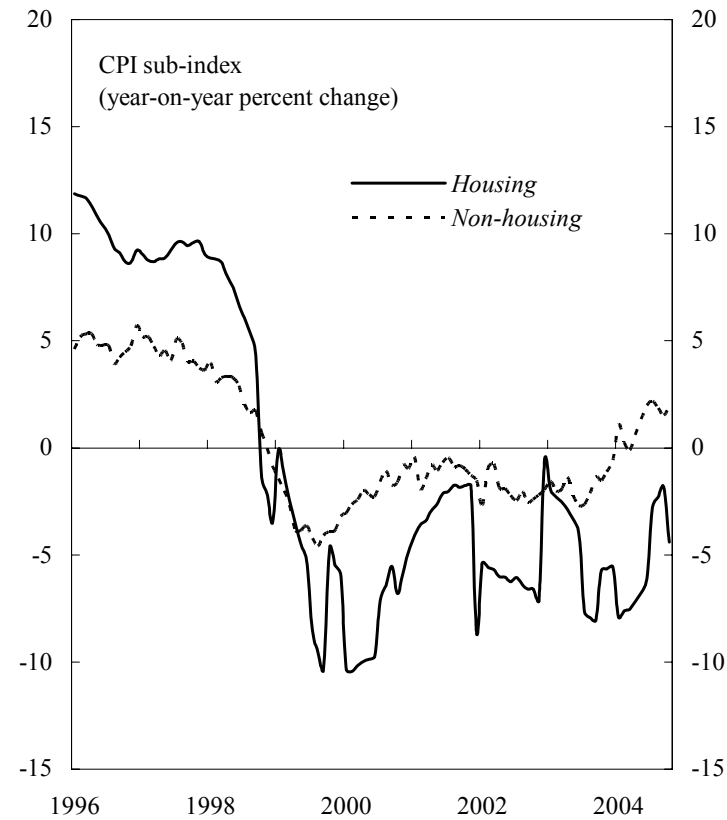

Both residential and commercial property prices have recovered significantly from depreciated since the Asian crisis, driven more recently by the weak U.S. dollar.

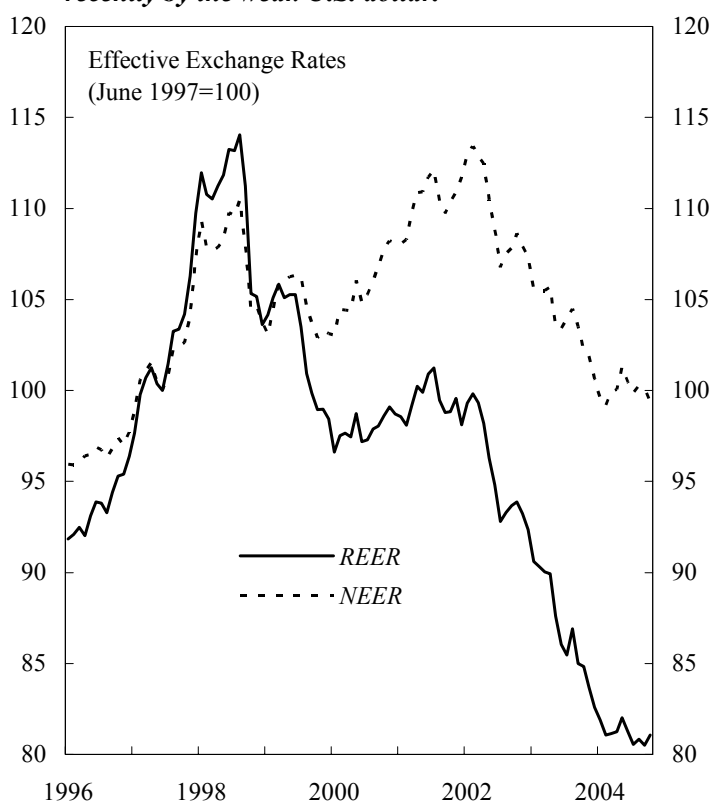

Sources: Data provided by the Hong Kong SAR authorities; and staff estimates. 
Figure 3. Hong Kong SAR: Labor Markets, 1996-2004

The unemployment rate reached its historic peak in mid-2003 and the NAIRU increased as well but both

10 have declined since then.
4

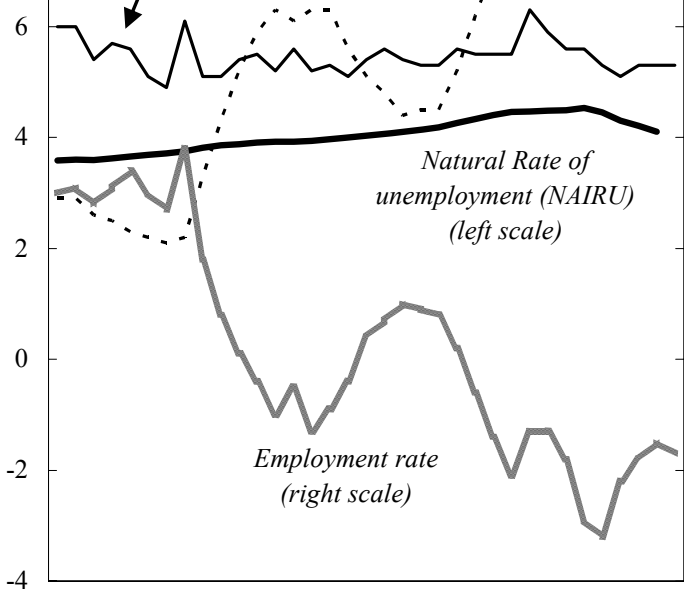

$19961997 \quad 19981999200020012002 \quad 2003 \quad 2004$
Nominal and real wage growth have declined until recently.

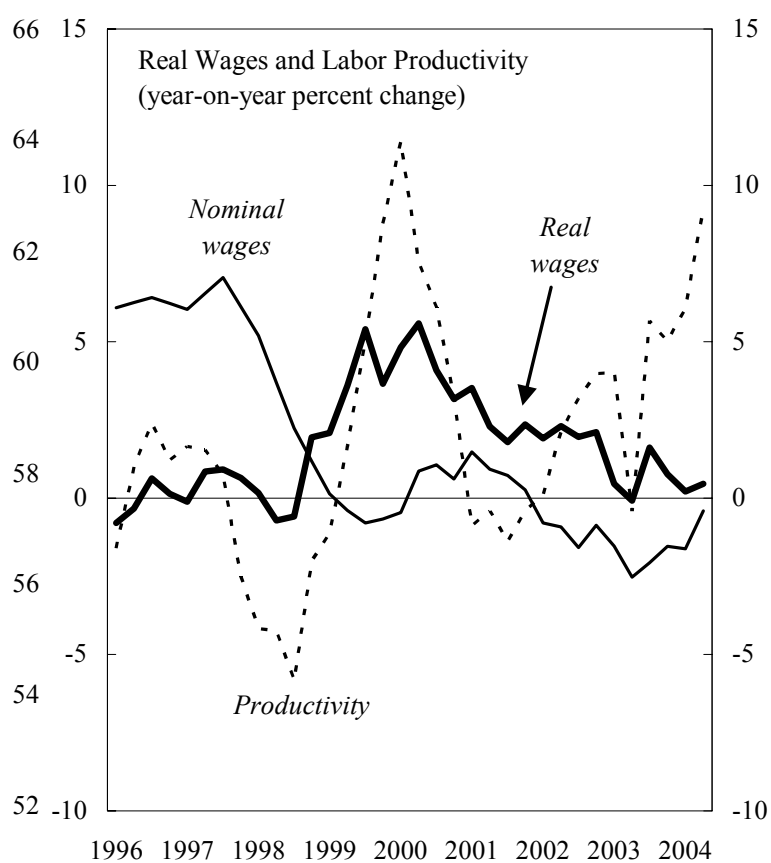

The structural transformation of the economy towards high value-added activities has led to erosion of the demand for low-skilled workers and increased the overall degree of mismatch in the labor market.
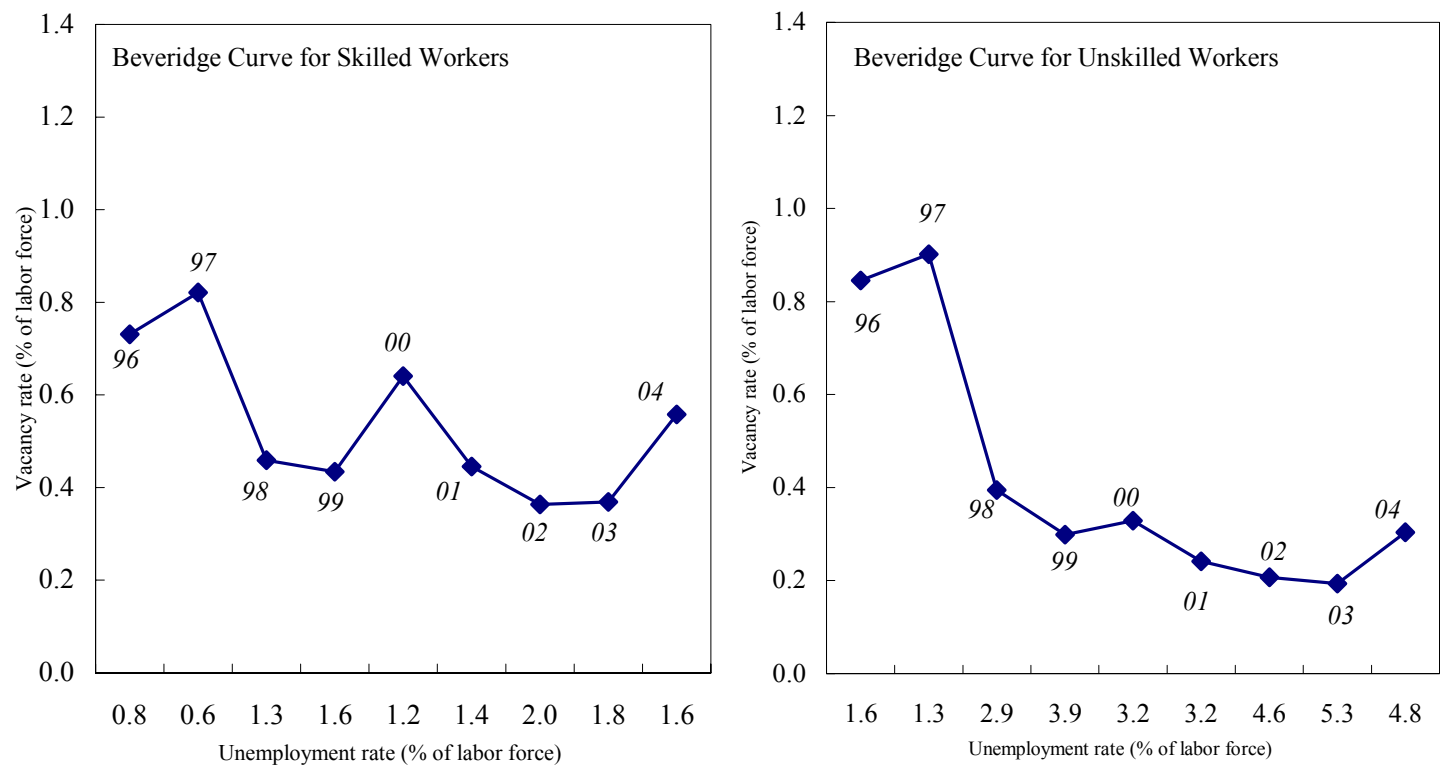

Sources: CEIC database and staff estimates. 
Figure 4. Hong Kong SAR: Financial Indicators, 1995-2004

Liquidity in the financial system has increased and credit growth has begun to recover.

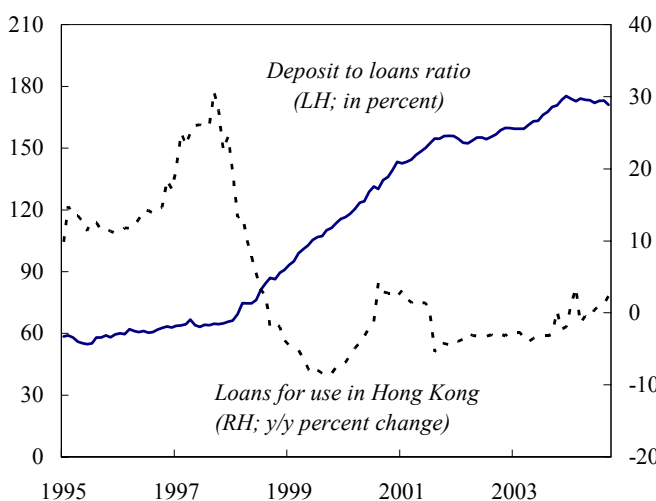

Nominal interest rates remain at very low levels...

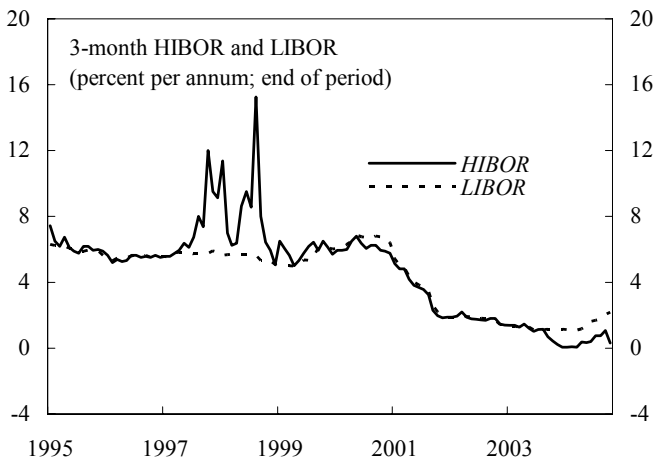

Bank capitalization has remained high and nonperforming loans have declined.

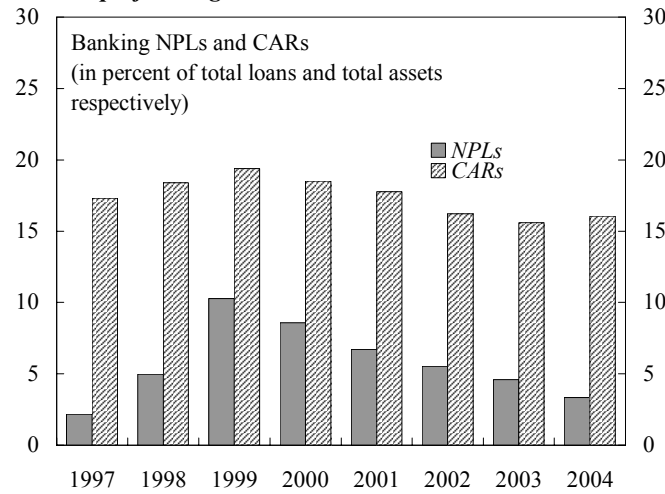

The forward premium on the Hong Kong dollar switched to a discount in late September 2003 and the discount has persisted in 2004.
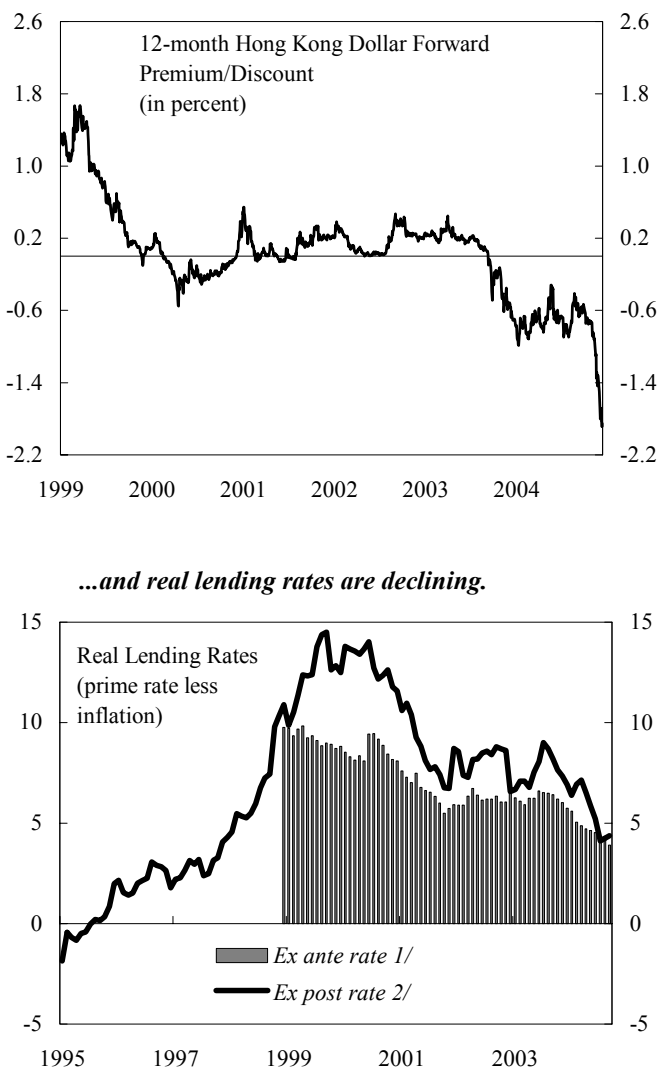

The stock market has recovered significantly since mid-2003, in line with global markets.

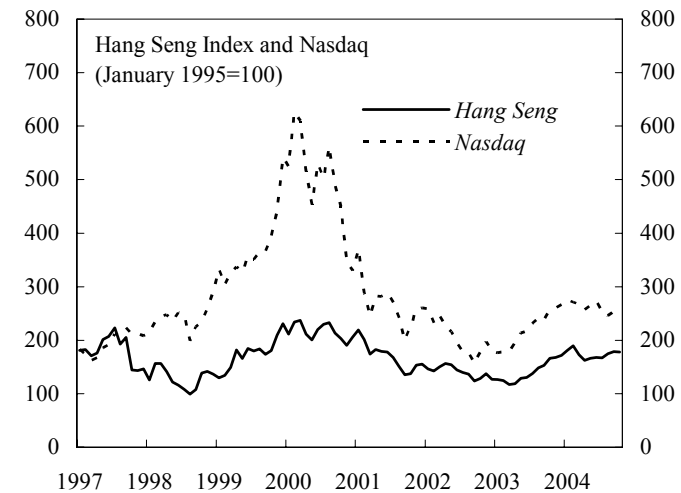

Sources: Data provided by the Hong Kong SAR authorities; and staff estimates.

$1 /$ Using consensus forecast of inflation.

2/ Using 12-month CPI inflation. 


\section{Figure 5. Hong Kong SAR: Fiscal Developments, FY1994/95-2004/05}

The consolidated fiscal deficit has declined significantly in FY2003/04; a similar performance is likely in FY2004/05.

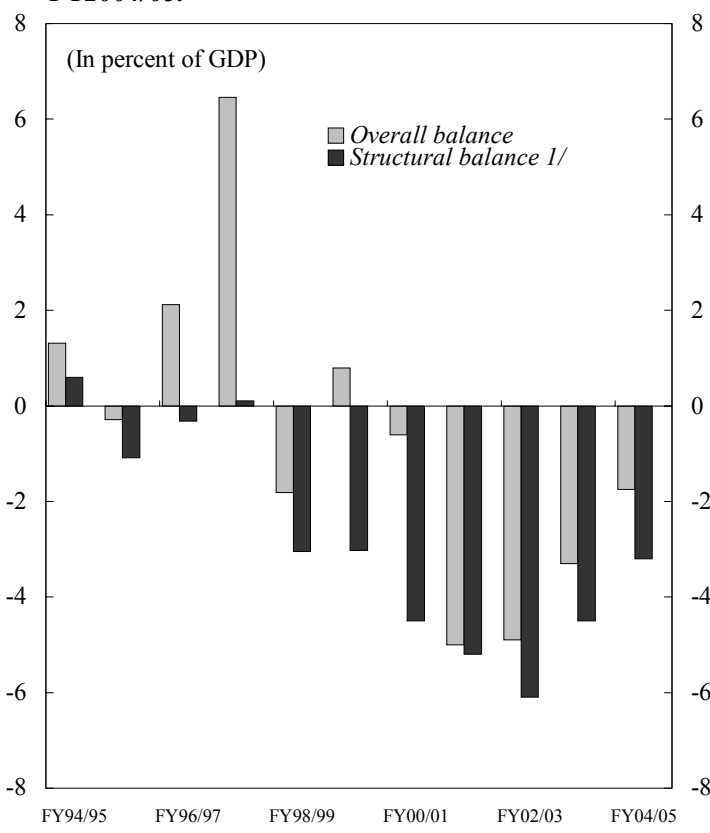

Revenue continues to be volatile...

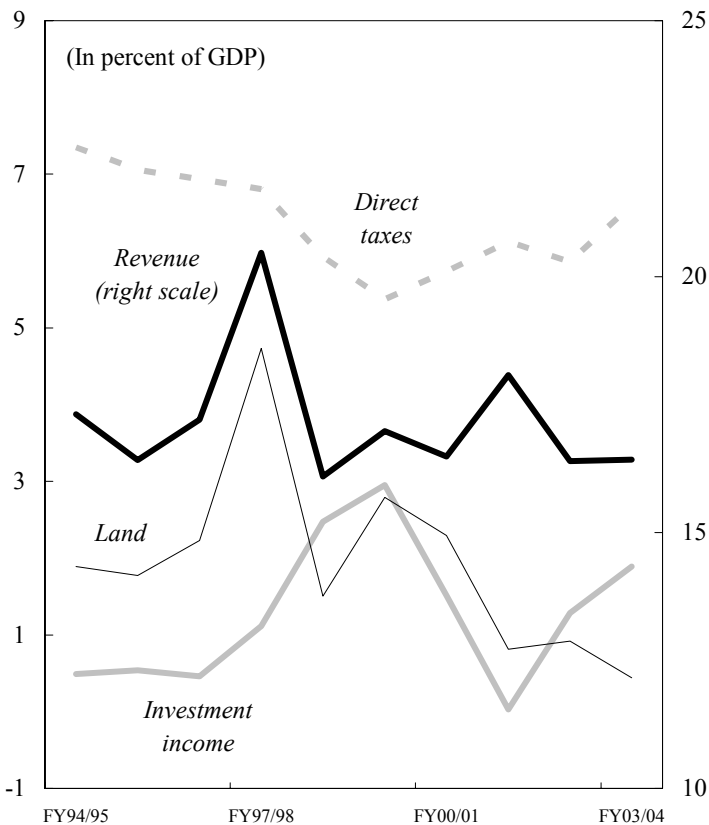

Fiscal policy, which was somewhat countercyclical until recently, now appears procyclical. 2/

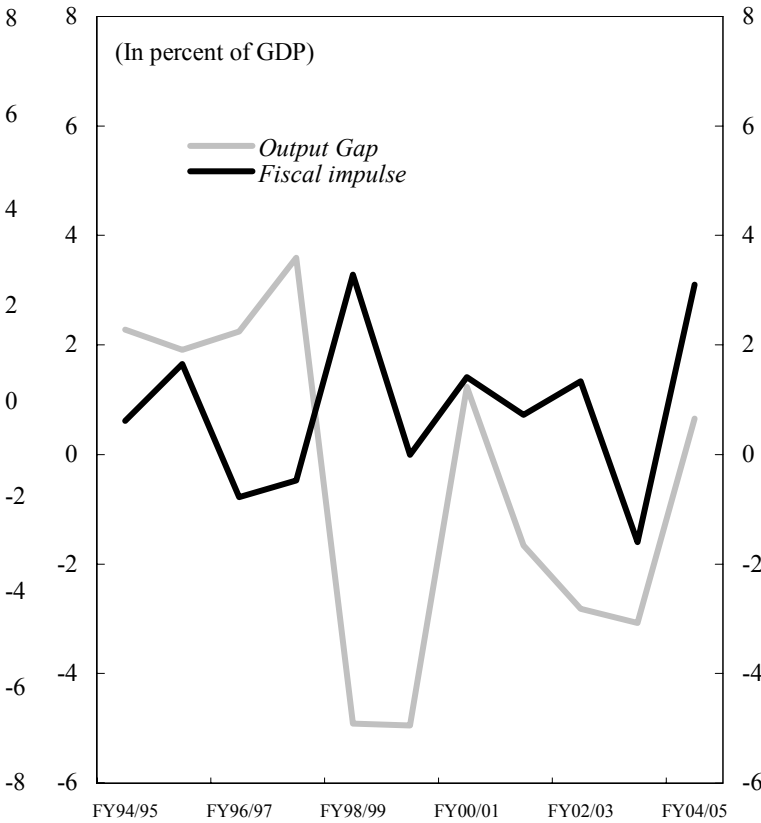

...and social expenditures have been rising until recently.

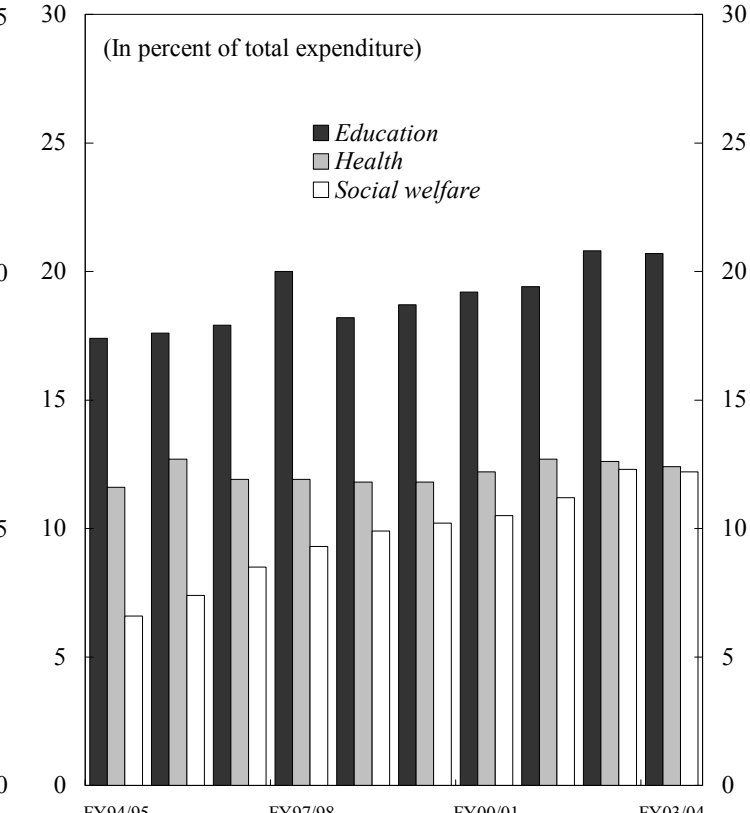
$-2$ 
Table 1. Hong Kong SAR: Selected Economic and Financial Indicators, 2002-2005

Nominal GDP (2003): US\$ 156.7 billion

Population (end-2003): 6.8 million

GDP per capita (2003): US\$23,030

\begin{tabular}{|c|c|c|c|c|c|c|c|c|c|c|c|}
\hline & \multirow[b]{2}{*}{2002} & \multirow[b]{2}{*}{2003} & \multicolumn{4}{|c|}{2003} & \multicolumn{3}{|c|}{2004} & \multicolumn{2}{|c|}{ Staff Proj. } \\
\hline & & & Q1 & Q2 & Q3 & $\overline{\mathrm{Q} 4}$ & Q1 & $\mathrm{Q} 2$ & $\mathrm{Q} 3$ & 2004 & 2005 \\
\hline Real GDP (percent change) & 1.9 & 3.2 & 4.4 & -0.6 & 4.0 & 4.9 & 7.0 & 12.1 & 7.2 & 8.2 & 4.0 \\
\hline Domestic demand (contribution) & -0.8 & 0.0 & 0.9 & -3.9 & -1.1 & 3.8 & 6.9 & 12.0 & 3.7 & 6.2 & 3.6 \\
\hline Private consumption & -0.7 & -0.5 & -2.0 & -2.5 & 0.1 & 2.0 & 3.4 & 6.5 & 2.7 & 4.1 & 2.4 \\
\hline Government consumption & 0.2 & 0.2 & 0.1 & 0.1 & 0.1 & 0.5 & 0.6 & 0.0 & -0.1 & 0.2 & 0.1 \\
\hline Gross fixed capital formation & -1.3 & 0.0 & 1.1 & -1.4 & 0.0 & 0.5 & 1.4 & 3.2 & 1.2 & 1.9 & 1.1 \\
\hline Inventories & 0.9 & 0.3 & 1.7 & 0.0 & -1.2 & 0.8 & 1.5 & 2.2 & -0.1 & 0.0 & 0.0 \\
\hline Net exports (contribution) & 2.7 & 3.2 & 3.5 & 3.3 & 5.1 & 1.0 & 0.0 & 0.1 & 3.4 & 2.1 & 0.4 \\
\hline Industrial production & -9.7 & -9.2 & -8.9 & -12.5 & -9.1 & -6.1 & 1.8 & 1.0 & $\ldots$ & $\ldots$ & $\ldots$ \\
\hline Retail sales & -2.6 & -0.6 & -1.1 & -7.7 & 1.3 & 5.2 & 7.8 & 15.7 & 6.7 & $\ldots$ & $\ldots$ \\
\hline \multicolumn{12}{|l|}{ Saving and investment (percent of GDP) } \\
\hline Gross domestic saving & 31.1 & 31.9 & 29.8 & 29.2 & 34.6 & 33.6 & 29.1 & 29.5 & 34.7 & 33.3 & 33.3 \\
\hline Gross domestic investment & 23.4 & 22.8 & 23.3 & 22.8 & 21.6 & 23.7 & 26.1 & 26.6 & 22.2 & 23.5 & 23.8 \\
\hline Saving-investment balance & 7.7 & 9.1 & 6.5 & 6.4 & 13.1 & 9.9 & 3.1 & 2.9 & 12.6 & 9.8 & 9.5 \\
\hline GDP deflator & -3.6 & -5.2 & -4.4 & -5.8 & -6.0 & -4.8 & -4.1 & -2.6 & -2.5 & -2.7 & 1.2 \\
\hline Employment (percent change) & -0.6 & -0.4 & 0.3 & -0.2 & -1.6 & -0.2 & 0.8 & 2.6 & 2.6 & 2.9 & 2.2 \\
\hline Unemployment rate (percent) & 7.3 & 7.9 & 7.5 & 8.6 & 8.3 & 7.4 & 7.2 & 6.9 & 6.8 & 6.4 & 5.6 \\
\hline Real wages & 1.3 & 0.1 & 0.3 & -0.2 & 0.7 & -0.3 & 0.2 & -0.5 & $\ldots$ & $\ldots$ & $\ldots$ \\
\hline \multicolumn{12}{|l|}{ Government budget (percent of GDP) } \\
\hline Revenue & 14.0 & 17.0 & $\ldots$ & $\ldots$ & $\ldots$ & $\ldots$ & $\ldots$ & $\ldots$ & $\ldots$ & 18.0 & 18.5 \\
\hline Expenditure & 19.0 & 20.2 & $\ldots$ & $\ldots$ & $\ldots$ & $\ldots$ & $\ldots$ & $\ldots$ & $\ldots$ & 19.7 & 18.7 \\
\hline Consolidated budget balance & -4.9 & -3.2 & $\ldots$ & $\ldots$ & $\ldots$ & $\ldots$ & $\ldots$ & $\ldots$ & $\ldots$ & -1.7 & -0.2 \\
\hline Fiscal reserves at March 31 & 25.0 & 22.3 & $\cdots$ & $\cdots$ & $\cdots$ & $\cdots$ & $\cdots$ & $\cdots$ & $\cdots$ & 19.5 & 18.4 \\
\hline \multicolumn{12}{|l|}{ Money and credit (percent change, end-period) } \\
\hline Narrow money (M1) & 14.6 & 39.8 & 14.5 & 19.8 & 27.5 & 39.8 & 45.5 & 39.3 & 27.4 & $\ldots$ & $\ldots$ \\
\hline Broad money (M3) & -0.9 & 8.3 & 1.9 & 2.4 & 5.6 & 8.3 & 8.7 & 6.9 & 6.4 & $\ldots$ & $\ldots$ \\
\hline Loans for use in Hong Kong SAR & -2.6 & -2.0 & -3.5 & -3.3 & -3.0 & -2.0 & -1.4 & 0.4 & 2.3 & $\cdots$ & $\ldots$ \\
\hline Three-month HIBOR & 1.5 & 0.1 & 1.3 & 1.1 & 0.8 & 0.1 & 0.1 & 0.4 & 1.5 & $\ldots$ & $\ldots$ \\
\hline \multicolumn{12}{|l|}{ Asset prices } \\
\hline Hang Seng stock index (July 31, 1964=100) & 9321 & 12576 & 8634 & 9577 & 11230 & 12576 & 12682 & 12286 & 13120 & $\ldots$ & $\ldots$ \\
\hline Hang Seng stock index (percent change) & -18.2 & 34.9 & -21.7 & -9.6 & 23.8 & 34.9 & 46.9 & 28.3 & 16.8 & $\ldots$ & $\ldots$ \\
\hline Residential property prices (percent change) & -11.1 & -12.0 & -15.0 & -17.1 & -14.1 & -0.6 & 17.3 & 29.5 & 29.5 & $\cdots$ & $\ldots$ \\
\hline \multicolumn{12}{|l|}{ Merchandise trade (percent change) $1 /$} \\
\hline Export volume & 8.6 & 14.0 & 19.1 & 14.2 & 9.8 & 14.2 & 14.8 & 18.0 & 15.5 & 16.8 & 6.5 \\
\hline Import volume & 7.8 & 12.8 & 18.6 & 10.6 & 7.9 & 15.0 & 15.6 & 19.9 & 14.2 & 15.3 & 6.8 \\
\hline Terms of trade & 1.2 & -1.0 & -0.7 & -1.1 & -0.9 & -1.3 & -1.4 & -1.8 & -2.0 & -1.9 & -0.8 \\
\hline \multicolumn{12}{|l|}{ External balances (percent of GDP) } \\
\hline Merchandise trade balance & -3.2 & -3.7 & -5.4 & -4.9 & -2.8 & -5.4 & -11.3 & -9.5 & -4.7 & -5.5 & -7.5 \\
\hline Current account balance & 7.9 & 10.7 & 12.4 & 5.7 & 14.1 & 10.4 & 5.2 & 2.4 & $\ldots$ & 9.8 & 9.5 \\
\hline \multicolumn{12}{|l|}{ Foreign exchange reserves $2 /$} \\
\hline In billions of U.S. dollars, end of period & 111.9 & 118.4 & 113.6 & 114.4 & 112.1 & 118.4 & 123.8 & 120.8 & 118.4 & $\ldots$ & $\ldots$ \\
\hline In months of retained imports & 22.6 & 23.1 & 22.4 & 22.9 & 22.6 & 23.1 & 23.2 & 21.0 & 19.9 & $\ldots$ & $\ldots$ \\
\hline In percent of broad money (M3) & 24.5 & 26.0 & 25.0 & 24.6 & 23.5 & 23.8 & 24.9 & 24.1 & 23.4 & $\ldots$ & $\ldots$ \\
\hline \multicolumn{12}{|l|}{ Exchange rate } \\
\hline Linked rate (fixed) & & & & 7.80/US & & & & & & & \\
\hline Market rate (HK\$/US\$1, period average) & 7.799 & 7.787 & 7.799 & 7.798 & 7.794 & 7.756 & 7.777 & 7.796 & 7.799 & $\ldots$ & $\ldots$ \\
\hline Real effective rate (period average, $1990=100$ ) & 137.7 & 125.2 & 130.1 & 126.5 & 123.6 & 120.6 & 117.2 & 117.4 & 116.4 & $\ldots$ & $\ldots$ \\
\hline
\end{tabular}

Sources: Data provided by the Hong Kong SAR authorities; and staff estimates and projections.

Staff projections are consistent with the latest WEO submission.

1/ Current month and previous two months compared with the same period of previous year.

2/ Includes Land Fund assets from 1997 (US\$17.5 billion at end- 1997). 


\begin{tabular}{|c|c|c|c|c|c|c|c|c|c|c|c|c|}
\hline & \multirow[t]{2}{*}{ FY00/01 } & \multirow{2}{*}{$\frac{\text { FY01/02 }}{\text { Actual }}$} & \multicolumn{2}{|c|}{ FY02/03 } & \multicolumn{2}{|c|}{ FY03/04 } & \multirow{2}{*}{$\frac{\text { FY04/05 }}{\text { Budget }}$} & \multirow{2}{*}{$\frac{\text { FY04/05 5/ }}{\text { Proj. }}$} & \multirow{2}{*}{$\frac{\text { FY05/06 }}{\text { Proj. }}$} & \multirow{2}{*}{$\frac{\text { FY06/07 }}{\text { Proj. }}$} & \multirow{2}{*}{$\frac{\text { FY07/08 }}{\text { Proj. }}$} & \multirow{2}{*}{$\frac{\text { FY08/09 }}{\text { Proj. }}$} \\
\hline & & & Budget & Actual & Budget & Est. & & & & & & \\
\hline Revenue & 17.5 & 13.8 & 17.2 & 14.2 & 15.2 & 17.0 & 15.9 & 18.0 & 18.5 & 17.8 & 17.6 & 17.6 \\
\hline Tax & 9.7 & 9.7 & 9.9 & 9.1 & 9.7 & 10.5 & 11.4 & 13.4 & 14.3 & 13.7 & 13.6 & 13.8 \\
\hline Earnings and profits tax & 5.7 & 6.1 & 5.9 & 6.3 & $\ldots$ & $\ldots$ & $\ldots$ & $\ldots$ & $\ldots$ & $\ldots$ & $\ldots$ & $\ldots$ \\
\hline Stamp duties & 0.8 & 0.7 & 0.9 & 0.9 & $\ldots$ & $\ldots$ & $\ldots$ & $\ldots$ & $\ldots$ & $\ldots$ & $\ldots$ & $\ldots$ \\
\hline Nontax & 7.8 & 4.1 & 7.3 & 5.1 & 5.5 & 6.5 & 4.6 & 4.6 & 4.2 & 4.2 & 4.0 & 3.8 \\
\hline of which: Land sales and Land Fund Revenue & 3.3 & 0.8 & 2.8 & 2.0 & 0.6 & 0.3 & 0.6 & 1.1 & 0.6 & 0.5 & 0.5 & 0.5 \\
\hline Investment income $2 /$ & 1.3 & 0.9 & 0.2 & 0.4 & 0.9 & 1.7 & 0.7 & 0.2 & 0.8 & 0.8 & 1.2 & 1.3 \\
\hline Privatization and asset sales & 0.8 & 0.0 & 1.3 & 0.0 & 1.6 & 1.3 & 2.4 & 2.3 & 1.8 & 1.5 & 1.1 & 1.0 \\
\hline Expenditure & 18.1 & 18.8 & 20.6 & 19.2 & 20.5 & 20.2 & 20.8 & 19.7 & 18.7 & 17.3 & 16.5 & 16.2 \\
\hline Current & 14.3 & 15.4 & 16.4 & 15.6 & 16.3 & 16.4 & 16.7 & 16.1 & 15.8 & 14.8 & 13.7 & 12.5 \\
\hline Capital & 3.8 & 3.4 & 4.2 & 3.6 & 4.2 & 3.8 & 4.1 & 3.6 & 2.9 & 2.5 & 2.8 & 3.8 \\
\hline Equity injections & 1.0 & 0.6 & 0.7 & 0.5 & 0.6 & 0.7 & 0.7 & 0.7 & 0.5 & 0.4 & 0.3 & 0.4 \\
\hline Other capital & 2.7 & 2.8 & 3.5 & 3.1 & 3.6 & 3.1 & 3.4 & 2.9 & 2.4 & 2.2 & 2.5 & 3.4 \\
\hline Primary balance 3 / & -1.9 & -5.8 & -3.6 & -5.3 & -6.1 & -4.9 & -5.6 & -1.9 & -1.0 & -0.3 & -0.1 & 0.2 \\
\hline Overall Balance & -0.6 & -5.0 & -3.4 & -4.9 & -5.3 & -3.2 & -4.9 & -1.7 & -0.2 & 0.5 & 1.0 & 1.5 \\
\hline Structural balance 4 / & -4.5 & -5.2 & -6.5 & -6.1 & -7.4 & -4.5 & -6.7 & -3.2 & -1.5 & -0.4 & 0.2 & 0.6 \\
\hline Fiscal reserves & 33.4 & 29.3 & 25.9 & 25.0 & 18.7 & 22.6 & 20.2 & 19.5 & 18.4 & 17.9 & 18.1 & 18.4 \\
\hline (in percent of annual expenditure) & 193 & 158 & 128.8 & 130.2 & 91.5 & 110.4 & 96.8 & 99.1 & 98.7 & 103.6 & 109.4 & 113.3 \\
\hline
\end{tabular}

Sources: Data provided by the Authorities; and staff estimates.

1/ Fiscal year begins April 1.

2/ As presented in the FY2002/03 budget proposed in March 2002.

3/ Balance excluding investment income.

e" is used by staff to measure the impact of fiscal policy on domestic demand.

It excludes asset-related transactions, land premium, investment income, privatization receipts, equity injections, and the impact of cyclical fluctuations.

5/ FY2004-08 are the staff's latest projections based on current policies. 
Table 3. Hong Kong SAR: Standard Vulnerability Indicators, 1998-2004

\begin{tabular}{|c|c|c|c|c|c|c|c|c|}
\hline \multirow{2}{*}{ Public Sector } & \multirow[t]{2}{*}{1998} & 1999 & 2000 & 2001 & 2002 & 2003 & \multicolumn{2}{|c|}{ 2004-latest } \\
\hline & & & & & & & & \\
\hline Fiscal deficit (in percent of GDP) & -1.8 & 0.8 & -0.6 & -5.0 & -4.9 & -3.2 & -2.2 & Oct. 2004 \\
\hline Accumulated fiscal surplus (in percent of GDP) & 33.9 & 35.7 & 33.4 & 29.3 & 25.0 & 22.6 & 19.9 & Oct. 2004 \\
\hline \multicolumn{9}{|l|}{ External Sector } \\
\hline Total Export volume (percent change) & -4.3 & 3.7 & 17.1 & -3.3 & 8.7 & 14.2 & 16.1 & Sep. 2004 \\
\hline Domestic exports & -7.9 & -7.2 & 7.6 & -10.2 & -11.2 & -7.3 & 1.7 & Sep. 2004 \\
\hline Reexports & -3.7 & 5.4 & 18.5 & -2.4 & 11.0 & 16.3 & 17.2 & Sep. 2004 \\
\hline Total Import volume (percent change) & -7.1 & 0.2 & 18.1 & -2.0 & 7.8 & 13.1 & 16.5 & Sep. 2004 \\
\hline Current account (in billions US\$) & 2.5 & 10.3 & 7.1 & 9.9 & 12.6 & 17.0 & 9.8 & Dec. 2004 \\
\hline Net equity inflow (in billions of US\$) & 6.4 & 30.0 & 29.3 & -23.5 & -14.4 & -3.0 & -12.7 & June 2004 \\
\hline Gross official reserves (in billions of US\$) & 89.6 & 96.3 & 107.6 & 111.2 & 111.9 & 118.4 & 125.0 & Nov. 2004 \\
\hline In months of retained imports & 17.1 & 19.8 & 18.0 & 20.4 & 22.6 & 23.2 & 20.4 & Nov. 2004 \\
\hline In percent of monetary base & 360.6 & 318.3 & 388.7 & 377.0 & 354.0 & 314.6 & 337.2 & Nov. 2004 \\
\hline In percent of broad money $1 /$ & 22.3 & 22.1 & 23.0 & 24.4 & 24.8 & 24.2 & 22.8 & Nov. 2004 \\
\hline In percent of Hong Kong dollar M3 & 37.7 & 38.6 & 41.9 & 43.0 & 43.5 & 43.4 & 43.1 & Nov. 2004 \\
\hline Short-term debt (in billions of US\$) 2/ & $\ldots$ & $\ldots$ & $\ldots$ & $\ldots$ & 28.7 & 31.2 & 38.6 & June 2004 \\
\hline In percent of gross reserves & $\ldots$ & $\ldots$ & $\ldots$ & $\ldots$ & 25.6 & 26.3 & 30.9 & June 2004 \\
\hline 1-yr forward exchange rate premium (in pips, annual average & 3285 & 1043 & -35 & 53 & 139 & 34.0 & -634.7 & Nov. 2004 \\
\hline Real exchange rate (percent change) & 7.7 & -6.9 & -3.5 & 1.5 & -4.2 & -9.3 & -7.7 & Oct. 2004 \\
\hline \multicolumn{9}{|l|}{ Financial Sector } \\
\hline HIBOR(3M)-LIBOR (3M) (in basis points) & 267.25 & 45.49 & -41.75 & -17.51 & -0.62 & -26.0 & -117.3 & Nov. 2004 \\
\hline Hang Seng Index (percent change, end-year) & -6.3 & 68.8 & -11.0 & -24.5 & -18.2 & 34.9 & 11.8 & Nov. 2004 \\
\hline Residential property prices (percent change, end-year) & -32.5 & -8.5 & -14.5 & -9.8 & -12.2 & 0.9 & 27.2 & Nov. 2004 \\
\hline \multicolumn{9}{|l|}{ Banking Sector $3 /$} \\
\hline Deposit-loans ratio 4/ & 90.8 & 115.6 & 143.3 & 155.9 & 159.8 & 175.3 & 176.9 & Oct. 2004 \\
\hline Domestic credit growth 5/ & -3.8 & -7.2 & 2.3 & -3.8 & -2.6 & -2.0 & 0.2 & Oct. 2004 \\
\hline Real credit growth & -6.4 & -3.3 & 6.3 & -2.3 & 0.4 & 0.6 & -0.1 & Oct. 2004 \\
\hline Capital adequacy ratio $5 /$ & 18.5 & 18.7 & 17.8 & 16.5 & 15.7 & 15.3 & 15.9 & June 2004 \\
\hline Nonperforming loans (in percent of total loans) $6,7 /$ & 7.7 & 10.1 & 7.3 & 6.5 & 5.0 & 3.9 & 3.0 & June 2004 \\
\hline Net interest margin (in percent of interest-bearing assets) 7/ & 2.0 & 2.1 & 2.1 & 2.0 & 2.1 & 1.9 & 1.7 & June 2004 \\
\hline Return on assets (post-tax) $7 /$ & 0.9 & 0.9 & 1.2 & 1.0 & 1.2 & 0.0 & 0.0 & June 2004 \\
\hline Net open spot position (in billions of US\$) & 6.2 & 12.4 & 25.7 & 24.7 & 18.2 & 15.9 & 21.3 & Oct. 2004 \\
\hline Net open forward position (in billions of US\$) & -3.6 & -5.2 & -18.7 & -14.6 & -6.7 & -6.4 & -16.3 & Oct. 2004 \\
\hline \multicolumn{9}{|l|}{ Contagion Indicator } \\
\hline HK\$-Renminbi forward exchange rate correlation (daily) & 0.73 & 0.57 & -0.06 & 0.12 & -0.12 & 0.9 & 0.8 & Nov. 2004 \\
\hline Hang Seng-NASDAQ correlation (daily) & 0.22 & 0.84 & 0.74 & 0.92 & 0.78 & 0.9 & 0.5 & Nov. 2004 \\
\hline
\end{tabular}

Sources: Hong Kong SAR authorities, BIS, and staff estimates.

1/ Broad Money refers to M2.

2/ Official statistics on Hong Kong SAR's external debt are available from the first quarter of 2002.

3/ For all authorized institutions, unless otherwise specified.

4/ Figures have been revised due to a change in the definition of customer deposits to include short-term Exchange Fund placements.

5/ For all locally incorporated authorized institutions.

6/ Refers to total loans classified as: "substandard", "doubtful" and "loss".

7/ For retail banks, which comprise all the locally incorporated banks plus a number of the larger foreign banks whose operations are similar to those of the locally incorporated banks in that they operate a branch network and are active in retail banking. 
Table 4. Hong Kong SAR: Medium-term Macroeconomic Framework, 1999-2009

\begin{tabular}{|c|c|c|c|c|c|c|c|c|c|c|c|c|}
\hline & \multirow{2}{*}{$\frac{\text { Average }}{1988-97}$} & \multicolumn{11}{|c|}{ Projections } \\
\hline & & 1999 & 2000 & 2001 & 2002 & 2003 & 2004 & 2005 & 2006 & 2007 & 2008 & 2009 \\
\hline Real GDP (percent change) & 5.2 & 3.4 & 10.2 & 0.5 & 1.9 & 3.2 & 8.2 & 4.0 & 4.0 & 4.0 & 4.0 & 4.0 \\
\hline \multicolumn{13}{|l|}{ Contribution } \\
\hline Real domestic demand & 6.8 & -4.0 & 9.8 & 0.9 & -0.8 & 0.0 & 6.2 & 3.6 & 3.5 & 3.5 & 3.5 & 3.5 \\
\hline Private consumption & 3.8 & 0.8 & 3.5 & 1.2 & -0.7 & -0.5 & 4.1 & 2.4 & 2.2 & 2.2 & 2.2 & 2.2 \\
\hline Gross fixed capital formation & 2.4 & -5.5 & 3.2 & 0.7 & -1.3 & 0.0 & 1.9 & 1.1 & 1.2 & 1.2 & 1.2 & 1.2 \\
\hline Inventories & 0.0 & 0.4 & 2.8 & -1.5 & 0.9 & 0.3 & 0.0 & 0.0 & 0.0 & 0.0 & 0.0 & 0.0 \\
\hline Net Exports & -1.6 & 7.4 & 0.4 & -0.5 & 2.7 & 3.2 & 2.1 & 0.4 & 0.5 & 0.5 & 0.5 & 0.5 \\
\hline Output gap (in percent of potential) & 1.4 & -4.9 & 1.2 & -1.7 & -2.8 & -3.1 & 0.7 & 0.6 & 0.4 & 0.3 & 0.2 & 0.0 \\
\hline \multicolumn{13}{|l|}{ Growth rates } \\
\hline Real domestic demand & 6.9 & -4.5 & 10.3 & 1.0 & -0.8 & 0.4 & 6.7 & 4.0 & 3.9 & 3.9 & 3.9 & 3.9 \\
\hline Government consumption & 5.0 & 3.1 & 2.0 & 6.1 & 2.5 & 1.9 & 2.0 & 1.0 & 1.0 & 1.0 & 1.0 & 1.0 \\
\hline Gross fixed capital formation & 9.0 & -16.6 & 11.0 & 2.6 & -4.5 & 0.1 & 7.4 & 4.5 & 4.7 & 4.7 & 4.7 & 4.7 \\
\hline \multicolumn{13}{|l|}{ Saving and investment (percent of GDP) } \\
\hline Gross national saving & n.a. & 31.7 & 32.4 & 31.8 & 31.3 & 33.1 & 33.3 & 33.3 & 33.3 & 33.4 & 33.3 & 33.3 \\
\hline Gross investment & 30.0 & 25.3 & 28.1 & 25.9 & 23.4 & 22.8 & 23.5 & 23.8 & 23.9 & 24.1 & 24.2 & 24.2 \\
\hline Saving-investment balance & n.a. & 6.4 & 4.3 & 5.8 & 7.9 & 10.3 & 9.8 & 9.5 & 9.4 & 9.4 & 9.1 & 9.1 \\
\hline \multicolumn{13}{|l|}{ Inflation (percent change) } \\
\hline Consumer prices & 8.9 & -4.0 & -3.7 & -1.6 & -3.0 & -2.6 & -0.3 & 1.0 & 1.1 & 1.2 & 1.4 & 1.5 \\
\hline GDP deflator & 7.8 & -5.9 & -6.2 & -1.9 & -3.6 & -5.2 & -2.7 & 1.2 & 1.3 & 1.7 & 2.1 & 2.3 \\
\hline Employment (percent change) & 1.7 & -0.3 & 3.1 & 1.3 & -0.5 & -0.3 & 2.9 & 2.2 & 2.2 & 2.2 & 2.2 & 2.2 \\
\hline Unemployment rate (percent) & 2.0 & 6.2 & 5.0 & 5.1 & 7.3 & 7.9 & 6.4 & 5.6 & 4.7 & 3.9 & 3.0 & 2.1 \\
\hline Real wages & 1.2 & 3.8 & 3.6 & 3.4 & 1.3 & 0.1 & $\ldots$ & $\ldots$ & $\ldots$ & $\ldots$ & $\ldots$ & $\ldots$ \\
\hline \multicolumn{13}{|l|}{ Government budget (percent of GDP) 1/ } \\
\hline Revenue & 17.3 & 18.7 & 17.5 & 13.8 & 14.2 & 17.0 & 18.0 & 18.5 & 17.8 & 17.6 & 17.6 & 17.8 \\
\hline Expenditure & 14.9 & 17.9 & 18.1 & 18.8 & 19.2 & 20.2 & 19.7 & 18.7 & 17.3 & 16.5 & 16.2 & 16.0 \\
\hline Consolidated budget balance & 2.4 & 0.8 & -0.6 & -5.0 & -4.9 & -3.2 & -1.7 & -0.2 & 0.5 & 1.0 & 1.5 & 1.8 \\
\hline Accumulated fiscal reserves (end-year) & 34.0 & 35.7 & 33.4 & 29.3 & 25.0 & 22.3 & 19.9 & 18.4 & 17.9 & 18.1 & 18.4 & 18.6 \\
\hline \multicolumn{13}{|l|}{ Merchandise trade (percent change) } \\
\hline Export volume & 13.0 & 3.7 & 17.1 & -3.3 & 8.7 & 14.2 & 16.8 & 6.5 & 6.6 & 6.7 & 6.7 & 6.7 \\
\hline Domestic exports & -0.3 & -7.2 & 7.6 & -10.2 & -11.2 & -7.3 & -4.0 & -3.0 & -2.0 & -1.0 & -1.0 & -1.0 \\
\hline Reexports & 19.3 & 5.4 & 18.5 & -2.4 & 11.0 & 16.3 & 18.4 & 7.1 & 7.1 & 7.1 & 7.1 & 7.0 \\
\hline Import volume & 13.9 & 0.2 & 18.1 & -2.0 & 7.8 & 13.1 & 15.3 & 6.8 & 6.8 & 6.8 & 6.8 & 6.8 \\
\hline Export value & 14.7 & 0.1 & 16.6 & -5.8 & 5.5 & 12.0 & 26.9 & 7.9 & 7.3 & 8.1 & 8.2 & 8.0 \\
\hline Import value & 16.0 & -2.5 & 19.2 & -5.3 & 3.4 & 12.0 & 27.7 & 9.0 & 7.5 & 8.2 & 8.2 & 7.9 \\
\hline Terms of trade & 0.1 & -0.7 & -0.9 & 0.9 & 1.2 & -1.3 & -1.9 & -0.8 & -0.1 & -0.1 & 0.0 & 0.2 \\
\hline \multicolumn{13}{|l|}{ External balances (in billions of US\$) } \\
\hline Trade balance & n.a. & -3.2 & -8.2 & -8.3 & -5.1 & -5.8 & -9.1 & -13.0 & -14.8 & -16.5 & -18.1 & -19.0 \\
\hline In percent of GDP & n.a. & -2.0 & -5.0 & -5.1 & -3.2 & -3.7 & -5.5 & -7.5 & -8.1 & -8.5 & -8.8 & -8.7 \\
\hline Exports of goods & n.a. & 175 & 202 & 191 & 200 & 224 & 285 & 307 & 329 & 356 & 385 & 416 \\
\hline Imports of goods & n.a. & 178 & 211 & 199 & 205 & 230 & 294 & 320 & 344 & 373 & 403 & 435 \\
\hline Current account & n.a. & 10.3 & 7.1 & 9.9 & 12.6 & 16.7 & 16.2 & 16.5 & 17.1 & 18.1 & 18.7 & 19.8 \\
\hline In percent of GDP & n.a. & 6.4 & 4.3 & 6.1 & 7.9 & 10.7 & 9.8 & 9.5 & 9.4 & 9.4 & 9.1 & 9.1 \\
\hline Foreign exchange reserves (end-year) & 42.9 & 96.3 & 107.6 & 111.2 & 111.9 & 118.4 & 125.0 & 123.0 & 124.0 & 125.1 & 126.2 & 127.4 \\
\hline In percent of GDP & 38.5 & 59.9 & 65.1 & 68.3 & 70.0 & 75.7 & 75.9 & 71.0 & 67.9 & 64.7 & 61.5 & 58.4 \\
\hline
\end{tabular}

Sources: Data provided by the Hong Kong SAR authorities; and staff estimates and projections.

$1 /$ The budget numbers refer to the fiscal year (April through March). 
Table 5. Hong Kong SAR: Medium-Term Balance of Payments, 1999-2009

\begin{tabular}{|c|c|c|c|c|c|c|c|c|c|c|c|}
\hline & & & & & & \multicolumn{6}{|c|}{ Projections } \\
\hline & 1999 & 2000 & 2001 & 2002 & 2003 & 2004 & 2005 & 2006 & 2007 & 2008 & 2009 \\
\hline & \multicolumn{11}{|c|}{ (In billions of U.S. dollars) } \\
\hline Current account & 10.3 & 7.1 & 9.9 & 12.6 & 16.7 & 16.2 & 16.5 & 17.1 & 18.1 & 18.7 & 19.8 \\
\hline Goods Balance & -3.2 & -8.2 & -8.3 & -5.1 & -5.8 & -9.1 & -13.0 & -14.8 & -16.5 & -18.1 & -19.0 \\
\hline Services balance & 10.5 & 14.1 & 14.8 & 17.4 & 20.0 & 21.9 & 25.6 & 27.8 & 30.2 & 32.8 & 35.6 \\
\hline Income Balance & 4.5 & 2.8 & 5.3 & 2.1 & 4.4 & 5.4 & 6.1 & 6.5 & 6.9 & 6.7 & 6.1 \\
\hline Transfer balance & -1.5 & -1.7 & -1.8 & -1.9 & -1.9 & -2.0 & -2.2 & -2.3 & -2.5 & -2.7 & -2.9 \\
\hline Capital and Financial Account & -10.7 & -7.4 & -12.5 & -19.4 & -23.0 & -12.8 & -13.6 & -15.0 & -14.7 & -14.4 & -14.0 \\
\hline Capital Account & -1.8 & -1.5 & -1.2 & -2.0 & -1.0 & -0.9 & -0.8 & -0.7 & -0.7 & -0.6 & -0.6 \\
\hline Financial Account & -9.0 & -5.9 & -11.3 & -17.4 & -21.4 & -11.9 & -12.8 & -14.3 & -14.1 & -13.8 & -13.4 \\
\hline Net Direct investment & 5.2 & 2.6 & 12.4 & -7.8 & 9.8 & 14.4 & 13.2 & 11.9 & 11.8 & 11.6 & 11.4 \\
\hline Portfolio investment & 33.1 & 24.5 & -41.3 & -38.8 & -34.0 & -23.7 & -21.9 & -19.9 & -19.9 & -19.7 & -19.5 \\
\hline Financial derivatives & 10.2 & 0.2 & 5.1 & 6.6 & 10.2 & 11.0 & 10.7 & 10.2 & 10.6 & 10.9 & 11.2 \\
\hline Net bank loans and other investment & -47.5 & -23.1 & 17.2 & 20.2 & -5.2 & -7.0 & -16.8 & -15.5 & -15.5 & -15.4 & -15.3 \\
\hline Reserve assets (net change) & -10.0 & -10.0 & -4.7 & 2.4 & -1.0 & -6.6 & 2.0 & -1.0 & -1.0 & -1.2 & -1.2 \\
\hline \multirow[t]{2}{*}{ Net errors and omissions } & 0.5 & 0.3 & 2.5 & 6.8 & 6.0 & -3.4 & -2.9 & -2.1 & -3.3 & -4.3 & -5.8 \\
\hline & \multicolumn{11}{|c|}{ (In percent of GDP) } \\
\hline Current account & 6.4 & 4.3 & 6.1 & 7.9 & 10.7 & 9.8 & 9.5 & 9.4 & 9.4 & 9.1 & 9.1 \\
\hline Goods Balance & -2.0 & -5.0 & -5.1 & -3.2 & -3.7 & -5.5 & -7.5 & -8.1 & -8.5 & -8.8 & -8.7 \\
\hline Services balance & 6.5 & 8.6 & 9.1 & 10.9 & 12.8 & 13.3 & 14.8 & 15.2 & 15.6 & 16.0 & 16.3 \\
\hline Income Balance & 2.8 & 1.7 & 3.2 & 1.3 & 2.8 & 3.3 & 3.5 & 3.5 & 3.6 & 3.3 & 2.8 \\
\hline Transfer balance & -1.0 & -1.0 & -1.1 & -1.2 & -1.2 & -1.2 & -1.3 & -1.3 & -1.3 & -1.3 & -1.3 \\
\hline Capital and Financial Account & -6.7 & -4.5 & -7.7 & -12.1 & -14.7 & -7.8 & -7.9 & -8.2 & -7.6 & -7.0 & -6.4 \\
\hline Capital Account & -1.1 & -0.9 & -0.7 & -1.3 & -0.6 & -0.6 & -0.5 & -0.4 & -0.3 & -0.3 & -0.3 \\
\hline Financial Account & -5.6 & -3.6 & -6.9 & -10.9 & -14.0 & -7.2 & -7.4 & -7.8 & -7.3 & -6.7 & -6.1 \\
\hline Net Direct investment & 3.3 & 1.6 & 7.6 & -4.9 & 5.2 & 8.7 & 7.6 & 6.5 & 6.1 & 5.6 & 5.2 \\
\hline Portfolio investment & 20.6 & 14.8 & -25.4 & -24.2 & -21.7 & -14.4 & -12.6 & -10.9 & -10.3 & -9.6 & -9.0 \\
\hline Financial derivatives & 6.4 & 0.1 & 3.1 & 4.1 & 6.5 & 6.7 & 6.2 & 5.6 & 5.5 & 5.3 & 5.1 \\
\hline Net bank loans and other investment & -29.6 & -14.0 & 10.5 & 12.6 & -3.3 & -4.3 & -9.7 & -8.5 & -8.0 & -7.5 & -7.0 \\
\hline Reserve assets (net change) & -6.2 & -6.1 & -2.9 & 1.5 & -0.6 & -4.0 & 1.1 & -0.6 & -0.5 & -0.6 & -0.5 \\
\hline Net errors and omissions & 0.3 & 0.2 & 1.6 & 4.2 & 3.8 & -2.0 & -1.7 & -1.2 & -1.7 & -2.1 & -2.7 \\
\hline
\end{tabular}

Sources: Hong Kong SAR authorities and staff estimates. 


\section{FUND RELATIONS}

\section{Membership Status}

As a Special Administrative Region of the People's Republic of China, Hong Kong SAR is not a member of the IMF. However, annual consultation discussions have been held with the Hong Kong SAR authorities since October 1990, and the staff also holds discussions with the authorities in connection with the IMF's Global Financial Stability reports. STA has provided Hong Kong SAR with technical assistance in the area of balance of payments statistics and Hong Kong SAR officials have attended INS courses on balance of payments and monetary statistics, and financial programming.

\section{Exchange Rate Arrangement}

The Hong Kong dollar has been linked to the U.S. dollar under a currency board arrangement since October 1983 at a rate of HK\$7.8/US\$1. There are no restrictions on current or capital account transactions in Hong Kong SAR, and the Hong Kong dollar is freely convertible. The People's Republic of China has accepted the obligations under Article VIII, Sections 2, 3 and 4 of the Articles of Agreement on December 1, 1996.

\section{Resident Representative}

The Hong Kong SAR sub-office of the Beijing Resident Representative's office was opened on September 23, 2000. Mr. Paul Gruenwald has served as the Resident Representative since August 2003. 


\section{STATISTICAL ISSUES}

Hong Kong SAR provides statistics to the Fund on a timely basis for surveillance and publication in International Financial Statistics (IFS). Hong Kong SAR subscribes to the SDDS and is fully compliant with its requirements.

In 2004, Hong Kong SAR published comprehensive international investment position statistics for the reference periods 2002 and 2003. It also published quarterly External Debt statistics for the reference period of the second quarter of 2004 according to the recommendations given in the External Debt Statistics: Guide for Compilers and Users.

Hong Kong SAR has for the first time reported GFS data for publication in the 2003 GFS Yearbook, but no data have been provided for publication in IFS. In January 2004, the authorities published their preliminary version of the accrual-based fiscal accounts starting with the FY2002/03 fiscal data, which does not strictly follow the Fund's Government Finance Statistics Manual (GFSM 2001). 
Hong Kong SAR: Survey of Reporting of Main Statistical Indicators

As of December 13, 2004

\begin{tabular}{|c|c|c|c|c|c|c|c|c|c|c|c|}
\hline & $\begin{array}{l}\text { Exchange } \\
\text { rates }\end{array}$ & $\begin{array}{l}\text { International } \\
\text { reserves }\end{array}$ & $\begin{array}{l}\text { Reserve/ } \\
\text { base } \\
\text { money }\end{array}$ & $\begin{array}{l}\text { Central } \\
\text { Bank } \\
\text { balance } \\
\text { sheet }\end{array}$ & $\begin{array}{l}\text { Broad } \\
\text { money }\end{array}$ & $\begin{array}{l}\text { Interest } \\
\text { rates }\end{array}$ & $\begin{array}{l}\text { Consumer } \\
\text { price } \\
\text { index }\end{array}$ & $\begin{array}{l}\text { Exports/ } \\
\text { Imports }\end{array}$ & $\begin{array}{l}\text { Current } \\
\text { account } \\
\text { balance }\end{array}$ & $\begin{array}{l}\text { Overall } \\
\text { government } \\
\text { balance }\end{array}$ & GDP/GNP \\
\hline $\begin{array}{l}\text { Date of latest } \\
\text { observation }\end{array}$ & $12 / 13 / 2004$ & $11 / 2004$ & $12 / 2004$ & $10 / 2004$ & $10 / 2004$ & $12 / 13 / 2004$ & $10 / 2004$ & $10 / 2004$ & $\mathrm{Q} 2 / 2004$ & $9 / 2004$ & Q3/2004 \\
\hline Date received & $12 / 13 / 2004$ & $12 / 2004$ & $12 / 2004$ & $11 / 2004$ & $11 / 2004$ & $12 / 13 / 2004$ & $11 / 2004$ & $11 / 2004$ & $9 / 2004$ & $11 / 2004$ & $11 / 2004$ \\
\hline $\begin{array}{l}\text { Frequency of } \\
\text { data }\end{array}$ & $\mathrm{D}$ & M & $\mathrm{D}$ & M & M & $\mathrm{D}$ & M & M & Q & M & Q \\
\hline $\begin{array}{l}\text { Frequency of } \\
\text { reporting }\end{array}$ & $\mathrm{D}$ & M & $\mathrm{D}$ & M & M & $\mathrm{D}$ & M & M & Q & M & Q \\
\hline $\begin{array}{l}\text { Frequency of } \\
\text { publication }\end{array}$ & $\mathrm{D}$ & M & $\mathrm{D}$ & M & M & $\mathrm{D}$ & M & M & Q & M & Q \\
\hline Source of data & $\mathrm{C}, \mathrm{N}$ & $\mathrm{N}$ & $\mathrm{N}$ & $\mathrm{N}$ & $\mathrm{N}$ & $\mathrm{C}, \mathrm{N}$ & $\mathrm{N}$ & $\mathrm{N}$ & $\mathrm{N}$ & $\mathrm{N}$ & $\mathrm{N}$ \\
\hline $\begin{array}{l}\text { Mode of } \\
\text { reporting }\end{array}$ & $\mathrm{E}, \mathrm{M}$ & $\mathrm{E}, \mathrm{M}$ & $\mathrm{E}, \mathrm{R}$ & $\mathrm{E}, \mathrm{M}$ & $\mathrm{E}, \mathrm{M}$ & $\mathrm{E}, \mathrm{M}$ & $\mathrm{E}, \mathrm{M}$ & $\mathrm{E}, \mathrm{M}$ & $\mathrm{E}, \mathrm{M}$ & $\mathrm{E}, \mathrm{M}$ & $\mathrm{E}, \mathrm{M}$ \\
\hline Confidentiality & $\mathrm{C}$ & $\mathrm{C}$ & $\mathrm{C}$ & $\mathrm{C}$ & $\mathrm{C}$ & $\mathrm{C}$ & $\mathrm{C}$ & $\mathrm{C}$ & $\mathrm{C}$ & $\mathrm{C}$ & $\mathrm{C}$ \\
\hline
\end{tabular}

1/ The codes are explained below.

Frequency of data: D - daily, M - monthly, Q - quarterly.

Frequency of reporting: $\mathrm{D}$ - daily, $\mathrm{M}$ - monthly, $\mathrm{Q}$ - quarterly, $\mathrm{P}$ - periodically (upon request).

Source of data: A - direct reporting by authorities, $\mathrm{N}$ - official publications and websites.

Mode of reporting: $\mathrm{E}$ - electronic data transfer, $\mathrm{M}$ - mail, F- fax, $\mathrm{R}$ - press report.

Confidentiality: $\mathrm{C}$ - unrestricted use, $\mathrm{D}$ - embargoed for a specific period, and for unrestricted use thereafter. 


\section{Statement by the IMF Staff Representative February 2, 2005}

1. This statement contains information that has become available since the staff report was circulated to the Executive Board on January 4, 2005. This information does not alter the thrust of the staff appraisal.

2. Some indicators of economic activity point to a moderation of economic growth in the fourth quarter of 2004, but it is difficult to draw firm conclusions prior to the release of GDP data. ${ }^{1}$ The slowdown in retail sales growth, from an average of about 10 percent (year-on-year) during January-October 2004 to 63/4 percent (year-on-year) in November, may be attributable to the decline in spending by tourists from the Mainland. External trade has also weakened - export growth slowed to about 13 percent (year-on-year) in December from 17 percent (year-on-year) in November. The consumer price index rose by 0.2 percent (yearon-year) in December 2004 (the same rate of increase as in November). The unemployment rate fell to 6.5 percent in December 2004 (from 6.7 percent in November).

3. The overall fiscal position continues to improve significantly. Following a good performance in the fourth quarter, investment income from the fiscal reserves in 2004 was HK \$14.5 billion, HK\$2.2 billion higher than projected in the FY2004/05 budget. As of endDecember 2004, fiscal reserves stood at about HK $\$ 273$ billion (about 21 percent of GDP; up from HK\$253 billion at end-September), sufficient to cover about 13 months of government expenditures.

4. Significant strong-side pressures on the Hong Kong dollar have persisted, although the discount in the one-year forward rate has eased in January 2005 . The forward discount — which implies expectations of an appreciation — has declined to about $1 \frac{1}{2}$ percent (compared to a record 2 percent in November 2004).

${ }^{1}$ GDP data for the fourth quarter will be released in March 2005. 
Public Information Notice (PIN) No. 05/25

FOR IMMEDIATE RELEASE

February 21, 2005
International Monetary Fund $70019^{\text {th }}$ Street, NW

Washington, D. C. 20431 USA

\section{IMF Concludes 2004 Article IV Consultation with the People's Republic of China-Hong Kong Special Administrative Region}

On February 2, 2005, the Executive Board of the International Monetary Fund (IMF) concluded the Article IV consultation with the People's Republic of China-Hong Kong Special Administrative Region. ${ }^{1}$

\section{Background}

After a period of prolonged weakness in economic activity, persistent deflation and rising fiscal deficits, the macroeconomic outlook has improved significantly since mid-2003. The recovery has gained significant momentum and become broad-based in 2004. The recovery was spurred by continued strong growth in the Mainland-complemented by the package of policy measures approved by the Mainland authorities for Hong Kong SAR - and the global recovery. The strong growth in the Mainland has provided a boost to growth in regional economies and the associated improvement in intra-regional trade has contributed to Hong Kong SAR's higher export growth. The easing of restrictions on individual travel from the Mainland to Hong Kong SAR helped to bolster tourism and private consumption. Investment spending also rose significantly as business sentiment improved. The unemployment rate has fallen by almost 2 percentage points from its peak last year, to 6.7 percent at end-November 2004. Strong domestic demand has contributed to the rebound of the property sector and the end of consumer price deflation. After five years of persistent price declines, the $\mathrm{CPI}$ index rose slightly

\footnotetext{
${ }^{1}$ Under Article IV of the IMF's Articles of Agreement, the IMF holds bilateral discussions with members, usually every year. A staff team visits the country, collects economic and financial information, and discusses with officials the country's economic developments and policies. On return to headquarters, the staff prepares a report, which forms the basis for discussion by the Executive Board. At the conclusion of the discussion, the Managing Director, as Chairman of the Board, summarizes the views of Executive Directors, and this summary is transmitted to the country's authorities.
} 
during July-November 2004. Residential property prices bottomed out in July 2003 , and have soared by about 40 percent since then, but remain below their peak in October 1997. The Hang Seng index has increased by about 70 percent since its trough in June 2003. The external current account surplus increased in 2003, in part due to the decline in domestic investment, however, it has narrowed in 2004, reflecting the increase in private consumption and the rise in domestic investment following the economic recovery.

The consolidated fiscal deficit for FY2004/05 (before bond issuance) is now projected at about $13 / 4$ percent of GDP, compared with the budget target of about 5 percent of GDP. The improvement relative to the budget is on account of buoyant revenue performance (reflecting stronger growth and large proceeds from land sales) and continued expenditure restraint. Fiscal reserves are projected at about 13 months of expenditures at the end of this fiscal year, well above the budget target of 10 months.

The staff projects that real GDP growth will decline from 81/4 percent in 2004 to 4 percent in 2005 , reflecting a slowing in global growth and some easing of activity on the Mainland. CPI inflation is expected to remain subdued in 2005. The unemployment rate should fall below 6 percent in 2005, with employment growth in the range of 2 to $2 \frac{1}{2}$ percent. The risks to this outlook are largely external. The downside risks are related to the durability of the global expansion, including the possible negative effects of persistently high oil prices. On the upside, there is some potential for stronger inbound tourism and more robust intra-regional trade.

\section{Executive Board Assessment}

Executive Directors commended the authorities for their skillful macroeconomic management, including their efforts to rein in the fiscal deficit. Directors noted that the economic recovery has become more broad-based in 2004, driven by the authorities' package of policy measures as well as the global recovery. Consumer price deflation appears to have ended, mainly reflecting robust domestic demand. Directors considered these achievements to be a testament to the resilience and flexibility of the Hong Kong SAR economy, especially given the significant external shocks of recent years.

Against the background of a promising near-term macroeconomic outlook, Directors noted that sustaining strong growth over the medium term will depend crucially on effectively managing the challenges of ongoing integration with the Mainland. In particular, Directors noted that Hong Kong SAR will need to continue to bolster its competitiveness by complementing its traditional strengths-flexible product and factor markets, and strong institutions-with sound macroeconomic policies and productivity-enhancing reforms.

Directors commended the authorities for continued expenditure restraint which, together with revenue buoyancy, has led to a significant decline in the fiscal deficit over the past two years. They welcomed the likelihood that budget balance on a consolidated basis will be achieved earlier than expected. Nevertheless, Directors encouraged the authorities to take advantage of the current favorable macroeconomic environment to forcefully address the long-standing 
structural deficit problem. They stressed that eliminating the structural deficit as soon as possible would help bolster fiscal reserves and facilitate adjustment to shocks that the economy might face. Directors welcomed the authorities' continued commitment to expenditure restraint, which will require careful monitoring of the civil service wage bill and adequate control of social expenditures.

Directors stressed that broadening the tax base and stabilizing revenues remains a key policy priority. They considered a goods and services tax (GST) as an appropriate instrument for improving the efficiency of the tax regime and reducing the reliance on volatile revenue sources. Directors welcomed the authorities' plans to engage in extensive public consultations in order to build consensus on the introduction of a GST. Given the long lead time required, Directors emphasized that technical preparations for the implementation of a GST will need to get under way without delay.

In addition, Directors encouraged the authorities to develop a longer-term focus for fiscal policy that takes into account potential fiscal pressures that are likely to arise from Hong Kong SAR's aging population. Such a focus could include targeting a higher level of fiscal reserves or net government assets.

Directors noted that the Hong Kong Monetary Authority has effectively managed pressures on the Hong Kong dollar over the past year and that the linked exchange rate system (LERS) remains robust. They reiterated their support for the authorities' commitment to the LERS.

Directors commended the Hong Kong SAR authorities for implementing the recommendations of the 2003 Financial Sector Assessment Program report, including the enhancement of regulatory and supervisory arrangements. They noted that the passage of legislation to introduce a deposit insurance scheme is a positive development-its launch in 2006 will further strengthen the banking system. Directors stressed that it was important for Hong Kong SAR to continue strengthening its financial infrastructure as well as its supervisory and regulatory systems in order to maintain its position as a leading international financial center. Directors welcomed the significant progress that has been made in strengthening the Anti-Money Laundering framework, including the issuance of relevant guidelines for its implementation.

Directors welcomed the progress made by the authorities in improving cooperation with their Mainland supervisory counterparts in the banking, securities, and insurance industries. They noted that coordination of supervisory activities between the two economies will become increasingly important as their integration intensifies.

Directors noted the progress made by the government in reducing its direct involvement in the property market and encouraged the authorities to take further steps in this direction. In this respect, they emphasized that continued provision of timely information about the government's plans concerning the supply of land will help reduce uncertainty and mitigate any associated instability in property prices. 
Directors emphasized that tackling structural unemployment is a key policy priority. They noted that outsourcing of manufacturing and low-end service sector jobs to the Mainland has reduced the demand for low-skilled workers in Hong Kong SAR. Directors expressed their support for the government's proposed education reforms and its ongoing retraining and skills-upgrading programs. They encouraged the authorities to maintain Hong Kong SAR's labor market flexibility, which has traditionally delivered good outcomes and will help facilitate adjustment to further shifts in the structure of the economy.

Public Information Notices (PINs) form part of the IMF's efforts to promote transparency of the IMF's views and analysis of economic developments and policies. With the consent of the country (or countries) concerned, PINs are issued after Executive Board discussions of Article IV consultations with member countries, of its surveillance of developments at the regional level, of post-program monitoring, and of ex post assessments of member countries with longer-term program engagements. PINs are also issued after Executive Board discussions of general policy matters, unless otherwise decided by the Executive Board in a particular case. The Staff Report for the 2004 Article IV Consultation with the People's Republic of China-Hong Kong Special Administration Region is also available. 
People's Republic of China, Hong Kong Special Administrative Region:

Selected Economic and Financial Indicators

\begin{tabular}{|c|c|c|c|c|c|c|}
\hline & 2000 & 2001 & 2002 & 2003 & 2004 & 2005 \\
\hline & & & & & \multicolumn{2}{|c|}{ Proj. } \\
\hline Real GDP (percent change) & 10.2 & 0.5 & 1.9 & 3.2 & 8.2 & 4.0 \\
\hline Real domestic demand (contribution) & 9.8 & 0.9 & -0.8 & 0.0 & 6.2 & 3.6 \\
\hline Foreign balance (contribution) & 0.4 & -0.5 & 2.7 & 3.2 & 2.1 & 0.4 \\
\hline \multicolumn{7}{|l|}{ Inflation (percent change) } \\
\hline Consumer prices & -3.7 & -1.6 & -3.0 & -2.6 & -0.3 & 1.0 \\
\hline GDP deflator & -6.2 & -1.9 & -3.6 & -5.2 & -2.7 & 1.2 \\
\hline \multicolumn{7}{|l|}{ Government budget (percent of GDP) $1 /$} \\
\hline Revenue & 17.5 & 13.8 & 14.2 & 17.0 & 18.0 & 18.5 \\
\hline Expenditure & 18.1 & 18.8 & 19.2 & 20.2 & 19.7 & 18.7 \\
\hline Consolidated budget balance & -0.6 & -5.0 & -4.9 & -3.2 & -1.7 & -0.2 \\
\hline \multicolumn{7}{|l|}{ External balances (in billions of US\$) } \\
\hline Merchandise trade balance & -8.2 & -8.3 & -5.1 & -5.8 & -9.1 & -13.0 \\
\hline In percent of GDP & -5.0 & -5.1 & -3.2 & -3.7 & -5.5 & -7.5 \\
\hline Current account balance & 7.1 & 9.9 & 12.6 & 17.0 & 16.2 & 16.5 \\
\hline In percent of GDP & 4.3 & 6.1 & 7.9 & 10.7 & 9.8 & 9.5 \\
\hline \multicolumn{7}{|l|}{ Foreign exchange reserves } \\
\hline \multicolumn{7}{|l|}{ Foreign exchange reserves } \\
\hline (in billions of U.S. dollars, end of period) & 107.6 & 111.2 & 111.9 & 118.4 & 123.5 & $\ldots$ \\
\hline (In months of retained imports) & 18.0 & 20.4 & 22.6 & 23.3 & 25.3 & $\ldots$ \\
\hline
\end{tabular}

Sources: Data provided by the Hong Kong SAR authorities; and IMF Staff estimates and projections.

1/ Fiscal year begins April 1. 